\title{
Using NASA's Molecular Adsorber Coating technology during thermal vacuum testing to protect critical laser flight optics on the ATLAS instrument
}

CONFERENCE PAPER 10748-14 | MONDAY, AUGUST 20, 2018

Nithin S. Abraham, Doris E. Jallice

NASA Goddard Space Flight Center 


\section{Project Team Members}

\begin{tabular}{|c|c|c|c|c|c|}
\hline $\begin{array}{l}\text { TEAM } \\
\text { MEMBER }\end{array}$ & $\begin{array}{l}\text { COMPANY AFFILIATION } \\
\text { \& ORGANIZATION CODE }\end{array}$ & $\begin{array}{l}\text { PROJECT } \\
\text { ROLE }\end{array}$ & $\begin{array}{l}\text { TEAM } \\
\text { MEMBER }\end{array}$ & $\begin{array}{l}\text { COMPANY AFFILIATION } \\
\text { \& ORGANIZATION CODE }\end{array}$ & $\begin{array}{l}\text { SUPPORT } \\
\text { ROLE }\end{array}$ \\
\hline $\begin{array}{l}\text { Nithin } \\
\text { Abraham }\end{array}$ & $\begin{array}{l}\text { NASA Goddard Space Flight Center } \\
\text { Code } 546 \text { Contamination and } \\
\text { Coatings Engineering Branch }\end{array}$ & $\begin{array}{l}\text { MAC Technologist/ } \\
\text { Thermal Coatings } \\
\text { Engineer }\end{array}$ & $\begin{array}{l}\text { Alfred } \\
\text { Wong }\end{array}$ & $\begin{array}{l}\text { Stinger Ghaffarian Technologies, Inc } \\
\text { Code } 546 \text { Contamination and } \\
\text { Coatings Engineering Branch }\end{array}$ & $\begin{array}{l}\text { Spray Application/ } \\
\text { Thermal Coatings } \\
\text { Engineer }\end{array}$ \\
\hline $\begin{array}{l}\text { Doris } \\
\text { Jallice }\end{array}$ & $\begin{array}{l}\text { NASA Goddard Space Flight Center } \\
\text { Code } 541 \text { Materials } \\
\text { Engineering Branch }\end{array}$ & $\begin{array}{l}\text { Chemical Analysis } \\
\text { Materials Engineer }\end{array}$ & $\begin{array}{c}\text { Mark } \\
\text { Hasegawa }\end{array}$ & $\begin{array}{l}\text { NASA Goddard Space Flight Center } \\
\text { Code } 546 \text { Contamination and } \\
\text { Coatings Engineering Branch }\end{array}$ & $\begin{array}{l}\text { Thermal Coatings } \\
\text { Engineering } \\
\text { Group Lead }\end{array}$ \\
\hline $\begin{array}{l}\text { Paul } \\
\text { Pless }\end{array}$ & $\begin{array}{l}\text { NASA Goddard Space Flight Center } \\
\text { Code } 541 \text { Materials } \\
\text { Engineering Branch }\end{array}$ & $\begin{array}{l}\text { Chemical Analysis } \\
\text { Materials Technician }\end{array}$ & $\begin{array}{l}\text { BonnieBlue } \\
\text { Valentin- } \\
\text { Santiago }\end{array}$ & $\begin{array}{l}\text { Stinger Ghaffarian Technologies, Inc } \\
\text { Code } 546 \text { Contamination and } \\
\text { Coatings Engineering Branch }\end{array}$ & $\begin{array}{l}\text { ATLAS } \\
\text { Contamination } \\
\text { Control Engineer }\end{array}$ \\
\hline $\begin{array}{l}\text { Deepak } \\
\text { Patel }\end{array}$ & $\begin{array}{l}\text { NASA Goddard Space Flight Center } \\
\text { Code } 545 \text { Contamination and } \\
\text { Coatings Engineering Branch }\end{array}$ & $\begin{array}{c}\text { ATLAS } \\
\text { Thermal Engineer }\end{array}$ & $\begin{array}{l}\text { David } \\
\text { Hughes }\end{array}$ & $\begin{array}{l}\text { NASA Goddard Space Flight Center } \\
\text { Code } 546 \text { Contamination and } \\
\text { Coatings Engineering Branch }\end{array}$ & $\begin{array}{l}\text { ATLAS } \\
\text { Contamination } \\
\text { Control Engineer }\end{array}$ \\
\hline $\begin{array}{c}\text { Matt } \\
\text { Garrison }\end{array}$ & $\begin{array}{l}\text { NASA Goddard Space Flight Center } \\
\text { Code } 545 \text { Contamination and } \\
\text { Coatings Engineering Branch }\end{array}$ & $\begin{array}{c}\text { ATLAS } \\
\text { Thermal Engineer }\end{array}$ & $\begin{array}{l}\text { Brandon } \\
\text { Stergiou }\end{array}$ & $\begin{array}{l}\text { Stinger Ghaffarian Technologies, Inc } \\
\text { Code } 546 \text { Contamination and } \\
\text { Coatings Engineering Branch }\end{array}$ & $\begin{array}{c}\text { ATLAS } \\
\text { Contamination } \\
\text { Control Technician }\end{array}$ \\
\hline $\begin{array}{l}\text { Heather } \\
\text { Bradshaw }\end{array}$ & $\begin{array}{l}\text { NASA Goddard Space Flight Center } \\
\text { Code } 545 \text { Contamination and } \\
\text { Coatings Engineering Branch }\end{array}$ & $\begin{array}{l}\text { ATLAS } \\
\text { Thermal Engineer }\end{array}$ & $\begin{array}{c}\text { Dong-Shiun } \\
\text { Lin }\end{array}$ & $\begin{array}{l}\text { Stinger Ghaffarian Technologies, Inc } \\
\text { Code } 546 \text { Contamination and } \\
\text { Coatings Engineering Branch }\end{array}$ & $\begin{array}{l}\text { ATLAS } \\
\text { Contamination } \\
\text { Control Analyst }\end{array}$ \\
\hline
\end{tabular}


The Molecular Adsorber Coating (MAC) is a sprayable coatings technology that was developed at NASA Goddard Space Flight Center (GSFC). The coating was designed to address molecular contamination concerns on or near sensitive surfaces and instruments within the spacecraft for flight or ground-based applications in vacuum conditions. This paper will discuss the use of NASA's MAC technology to isolate and protect the critical laser flight optics of the Advanced Topographic Laser Altimeter System (ATLAS) instrument on the Ice, Cloud, and land Elevation Satellite-2 (ICESat-2). MAC was strategically used during thermal vacuum (TVAC) testing efforts to reduce the risk of contaminating the laser optical components from non-baked items and other unknown outgassing sources from the chamber environment. This paper summarizes the design and implementation efforts, and the chemical analysis of the MAC samples that were used during two recent TVAC tests for the ICESat2/ATLAS mission.

- Keywords: molecular adsorber coating, molecular adsorbers, getters, MAC, zeolite, coatings technology, outgassing, molecular contamination, vacuum contamination, thermal vacuum, TVAC, ICESat-2, ATLAS, vacuum chambers, chamber facility, flight optics, laser optics, optical components 


\section{Presentation Outline}

\section{INTRODUCTION}

APPROACH

TEST METHODS

RESULTS \& DISCUSSION

\section{SUMMARY}

- ATLAS Instrument

- Molecular Adsorber Coatings

- Purpose

- Sample Fabrication \& Exposure

- Sample Location

- Sample Configuration

- Temperature Profile

- Solvent Rinse Methods

- Chemical Analysis Methods

- Solvent Rinse Results

- Molecular Adsorption Capacity

- Chemical Analysis Results

- Comparison to Contamination Monitoring Methods

- Conclusions

- Future Work

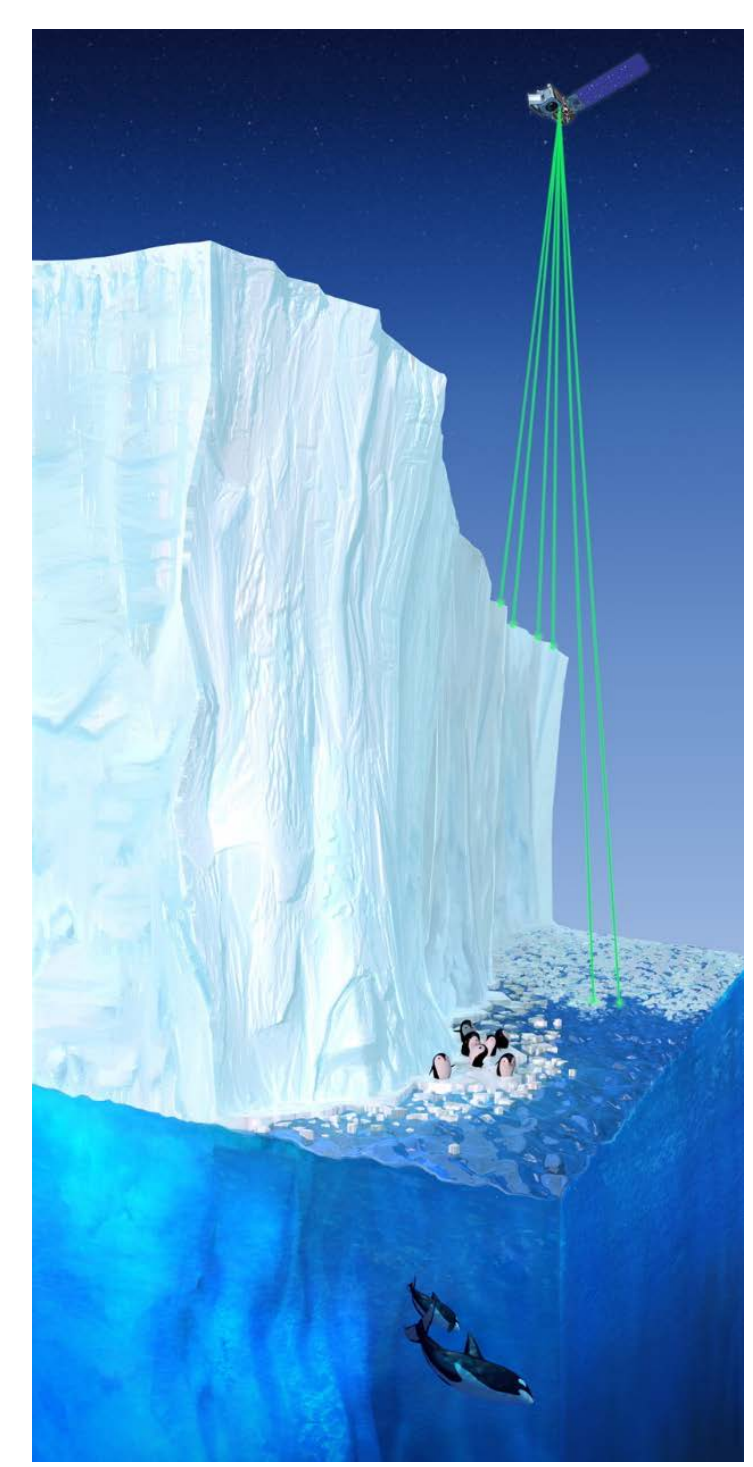




\section{Introduction}

- ATLAS Instrument

- Molecular Adsorber Coatings 


\section{ATLAS Instrument}

- ICESat-2

- Ice, Cloud and land Elevation Satellite-2

- NASA mission that will study the cryosphere to investigate the changes in the Earth's frozen and icy regions due to the warming climate

\section{- ATLAS}

- Advanced Topographic Laser Altimeter System

- Built by NASA Goddard Space Flight Center

- Sole instrument on ICESat-2 spacecraft that will measure the height of:

- Glaciers

- Ice sheets

- Sea ice

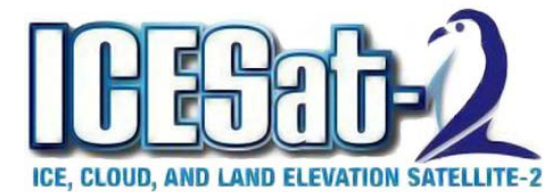

- Rain forests

- Deserts

- Urban areas
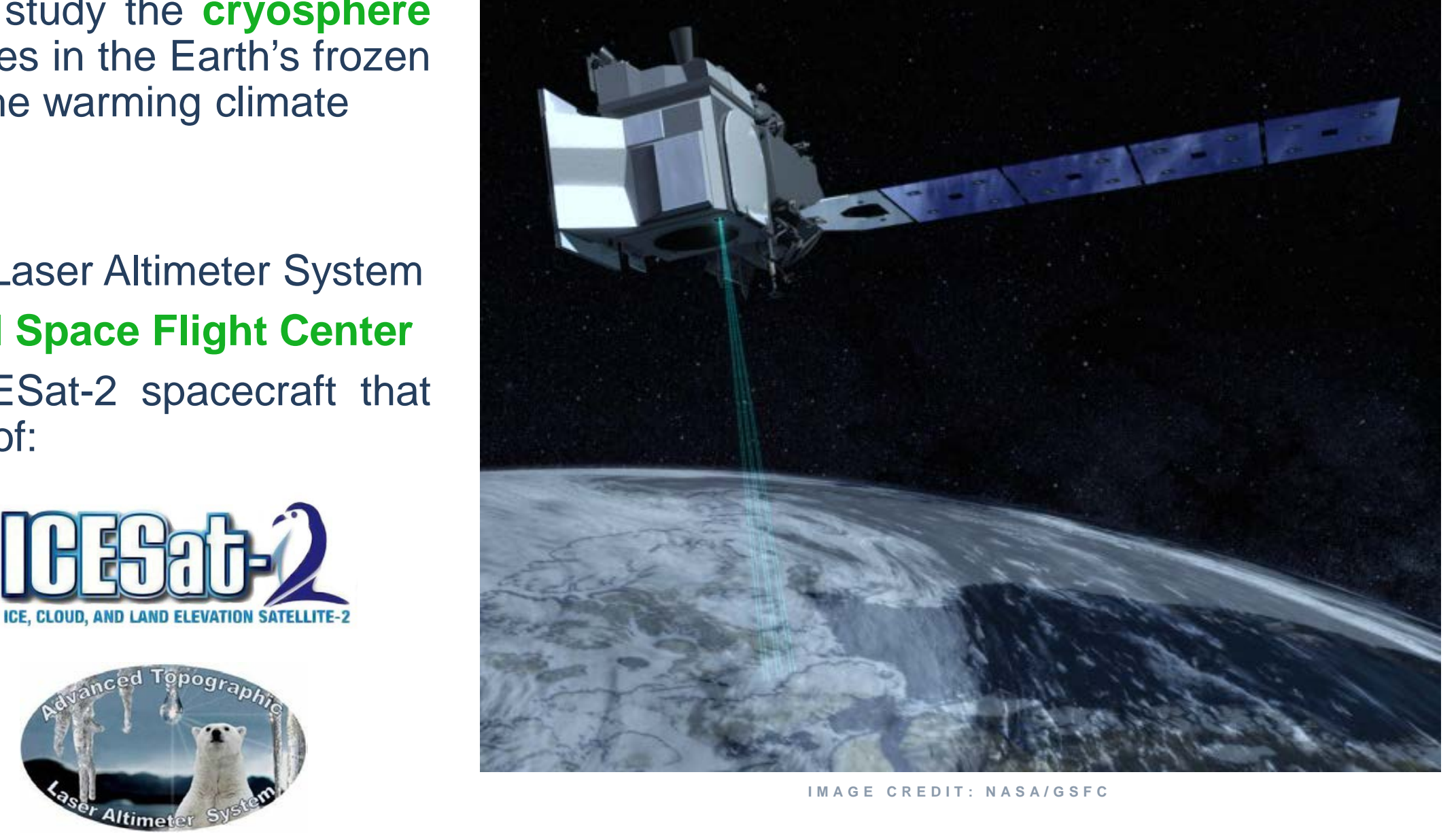


\section{ATLAS Instrument}

- Instrument's three main tasks are to:

- Send laser pulses of visible green light to Earth

- Catch returning photons using its precisely aligned beryllium telescope

- Record travel time of each returned photon to calculate distance between the spacecraft and Earth

Wavelength $532 \mathrm{~nm}$

Beams $\quad$ Single laser split into 6 beams \& arranged into 3 pairs

Travel Rate

Measurement

Photons Sent

About 200 trillion

Photons Return

About a dozen

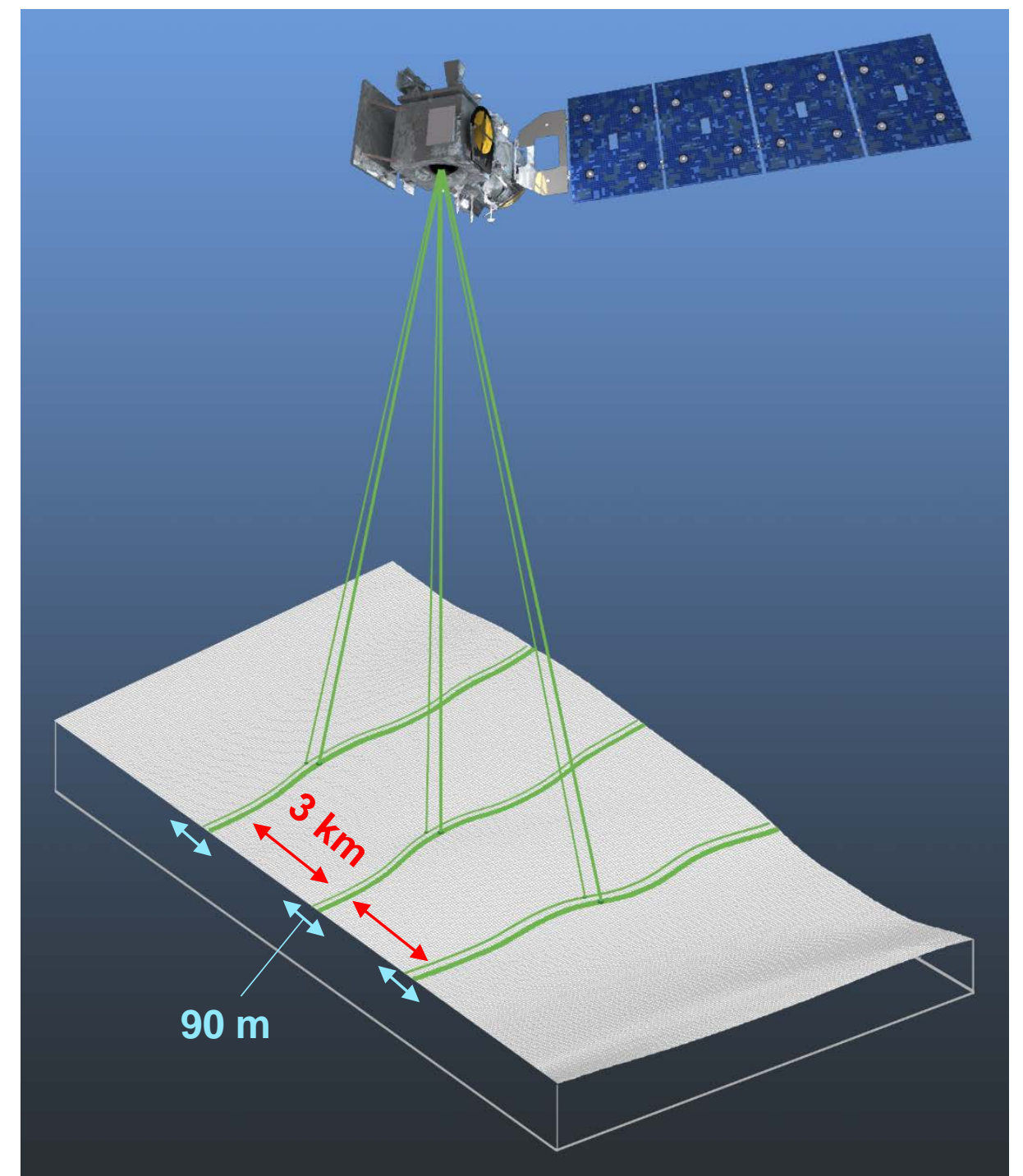

IMAGE CREDIT: NASAIGSFC 


\section{ATLAS Instrument}

Prior to sending the laser beam down to Earth:

- Photons must first travel through a series of critical optical components, such as lenses and mirrors, along the instrument's optical bench in order to:

- Align the laser and the telescope

- Check the wavelength of the laser

- Start the timing mechanism

- Determine the size of the ground footprint

- Split the single laser into 6 beams

Therefore, protecting the critical laser flight optics on the ATLAS instrument is important to the successful operation of the satellite
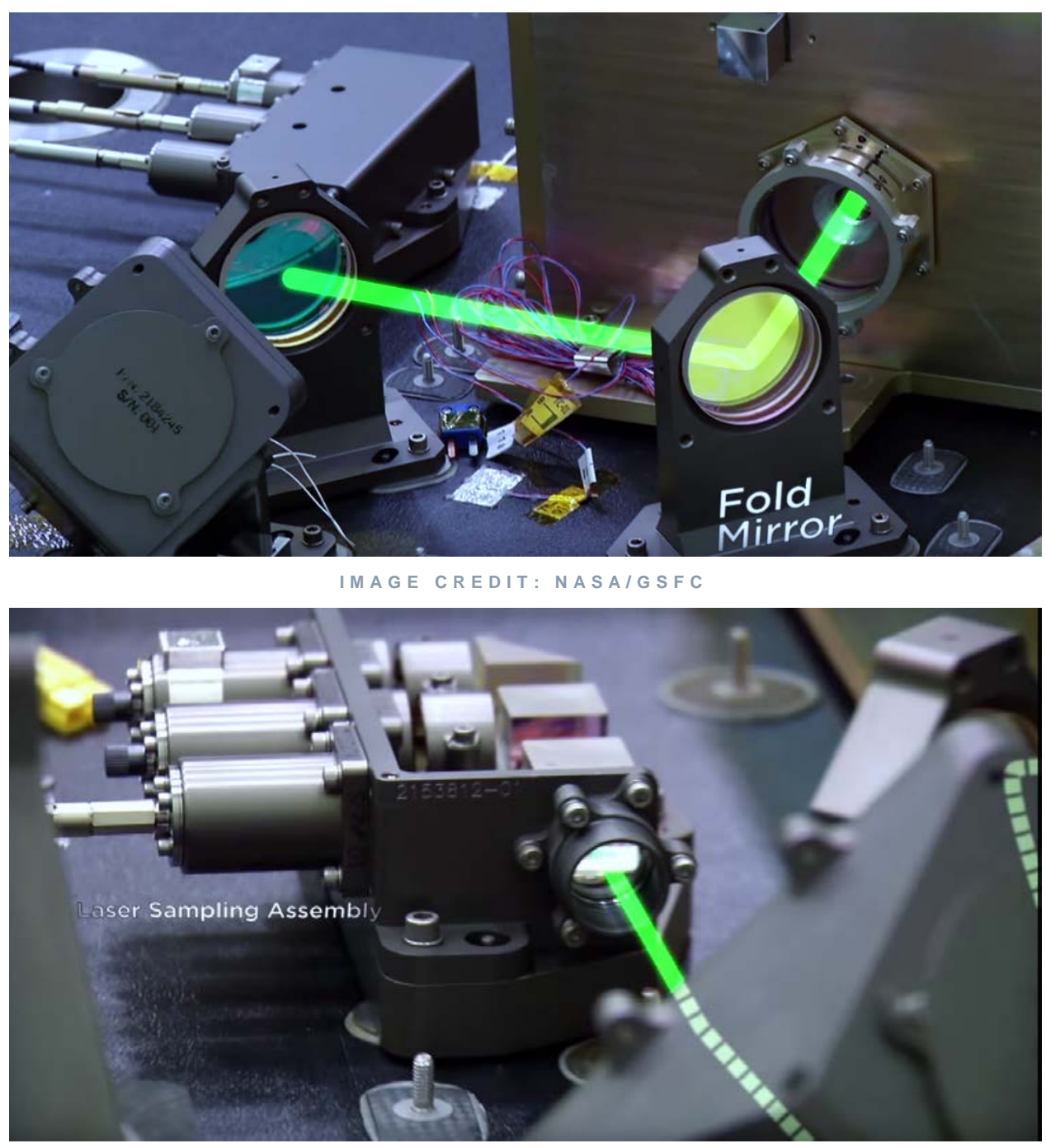


\section{ATLAS Instrument}

POTENTIAL PROBLEM

Catastrophic impacts of contamination result in laser induced optical damage and performance degradation in spaceflight laser systems

Molecular contaminants, such as silicones and aromatic hydrocarbons, are particularly known to damage laser optics

\section{PROPOSED MITIGATION}

Consequently, it is important to reduce the risk of exposure from potential molecular contaminants throughout the various phases of a NASA mission, particularly during the I\&T phases of the project
A contamination control mitigation method that was proposed was the strategic placement of MAC samples during TVAC testing of ATLAS hardware in vacuum test chambers 


\section{Molecular Adsorber Coatings}

\section{- Molecular Adsorber Coating (MAC)}

- Sprayable coatings technology

- Developed by NASA Goddard Space Flight Center

- Addresses molecular outgassing concerns

- Comprised of zeolite-based, porous materials

- Passively captures molecular contaminants

- Has low outgassing materials

- Effective in trapping high molecular weight chemical species, such as hydrocarbons, silicones, plasticizers, and other outgassed constituents from common spaceflight materials
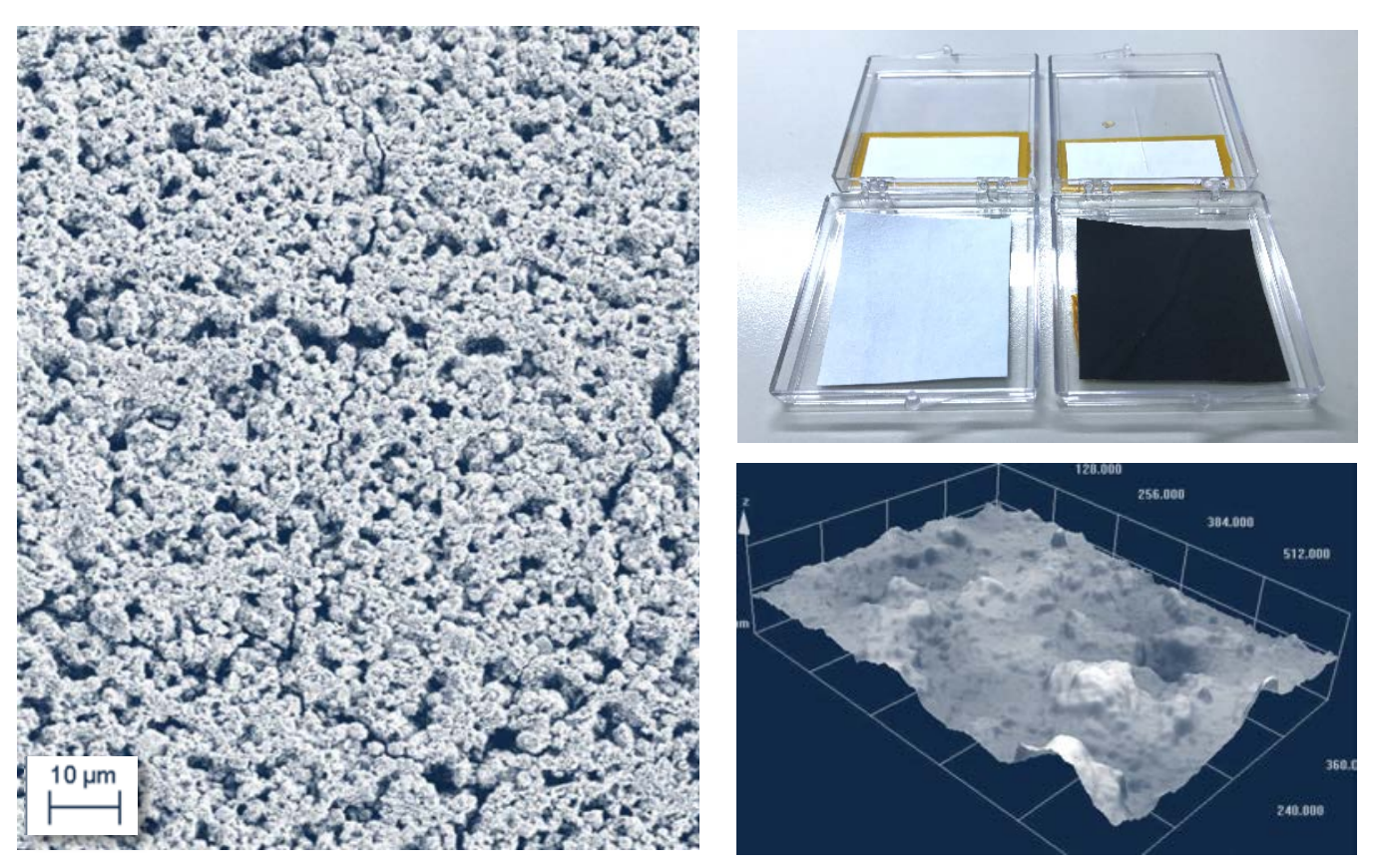

IMAGE CREDIT: NASA/GSFC

- Used in on-orbit spaceflight applications, particularly on or near sensitive surfaces and components on the spacecraft, such as instrument cavities, electronics boxes, and detectors

Ionospheric Connection Explorer (ICON): MAC plates were installed in the Far Ultraviolet (FUV) instrument to address on-orbit material outgassing concerns 


\section{Molecular Adsorber Coatings}

- MAC has also been extensively used in ground-based applications as a passive getter material during TVAC testing to mitigate the risk of molecular contamination on many NASA missions

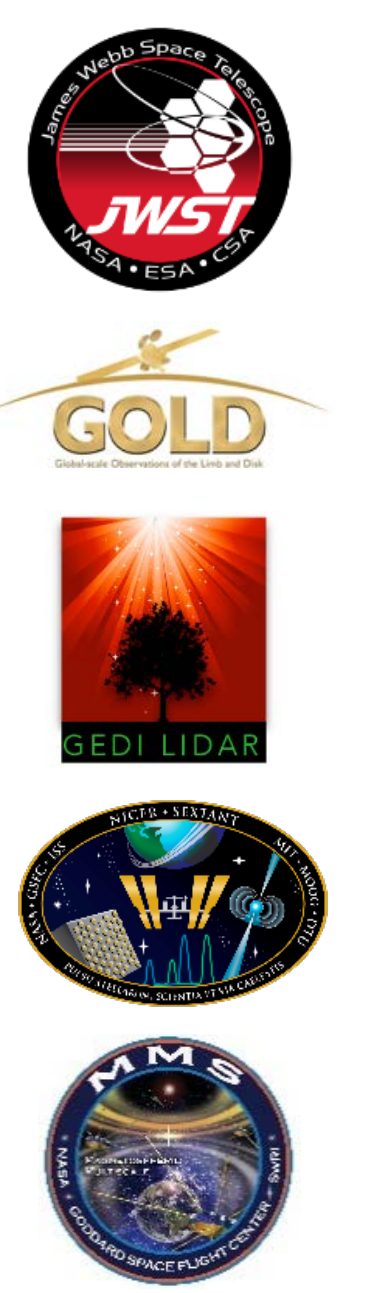

\begin{tabular}{|c|c|}
\hline & NASA MISSION \\
\hline JWST & $\begin{array}{l}\text { James Webb } \\
\text { Space Telescope }\end{array}$ \\
\hline GOLD & $\begin{array}{l}\text { Global-scale Observations } \\
\text { of the Limb and Disk }\end{array}$ \\
\hline GEDI & $\begin{array}{l}\text { Global Ecosystem Dynamics } \\
\text { Investigation Lidar }\end{array}$ \\
\hline NICER & $\begin{array}{l}\text { Neutron star Interior } \\
\text { Composition Explorer }\end{array}$ \\
\hline MMS & $\begin{array}{l}\text { Magnetosphere } \\
\text { Multiscale Mission }\end{array}$ \\
\hline
\end{tabular}

TVAC PURPOSE

Used during testing of optical ground support equipment (OGSE), thermal pathfinder

(TPF), and optical telescope element and integrated science (OTIS) instruments

Used during instrument level testing

Used during component level testing

Used during component level testing

Used during component level testing
YEAR 2017 2016 2015 2014

2017

2016

2015

2014 


\section{Approach}

- Purpose

- Sample Fabrication \& Exposure

- Sample Location

- Sample Configuration

- Temperature Profile 
- MAC samples were deployed during two TVAC tests to isolate and protect the critical laser flight optics on the ATLAS instrument from outgassing sources

- Potential sources may originate from commonly used spaceflight materials and components, TVAC test set-up and chamber environment, or from other unknowns

- Time-temperature bake-outs were performed on most items prior to the tests; however, it does not completely eliminate the possibility of outgassing, especially from materials comprised of silicones or elastomers

- Potential sources may also contribute to molecular reflection that would not be indicative of the on-orbit flight case due to the confined space and warm walls of the chamber

- Location of existing facility scavenger cold plates would not isolate critical optical components from all possible outgassing sources

\section{POTENTIAL OUTGASSING SOURCES}

- Staking Compounds

- Adhesives

- Epoxies

- Cables \& Wires

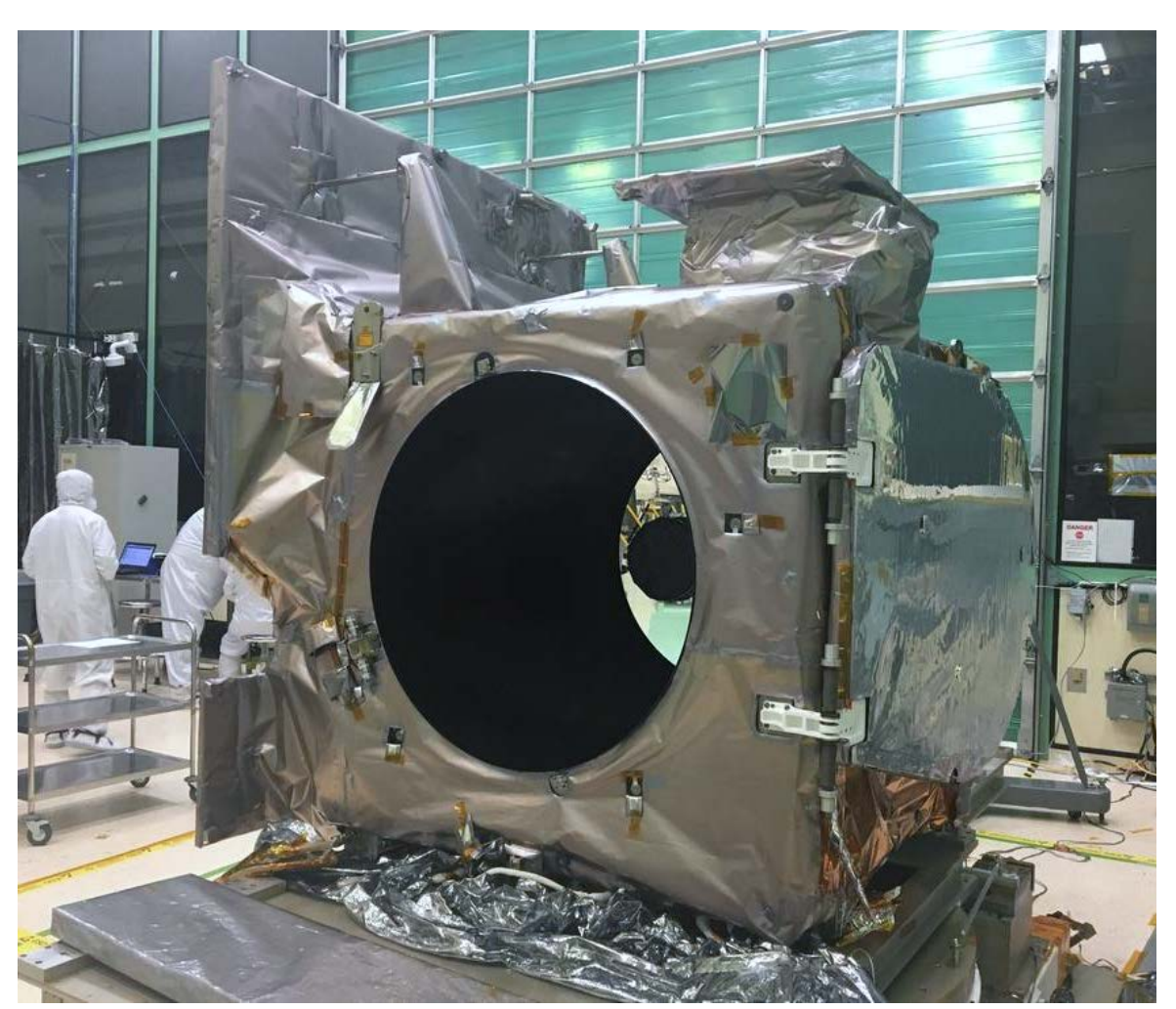




\section{Sample Fabrication \& Exposure}

- NASA GSFC custom-fabricated samples coated with the white version of MAC

\begin{tabular}{|c|}
\hline COATING TYPE \\
\hline SUBSTRATE \\
\hline COATING THICKNESS \\
\hline COATING AREA \\
\hline
\end{tabular}

\begin{tabular}{|c|}
\hline MAC-W \\
Aluminum Alloy \\
6.2 mils \\
$95.2 \mathrm{~cm}^{2}$ \\
\hline
\end{tabular}

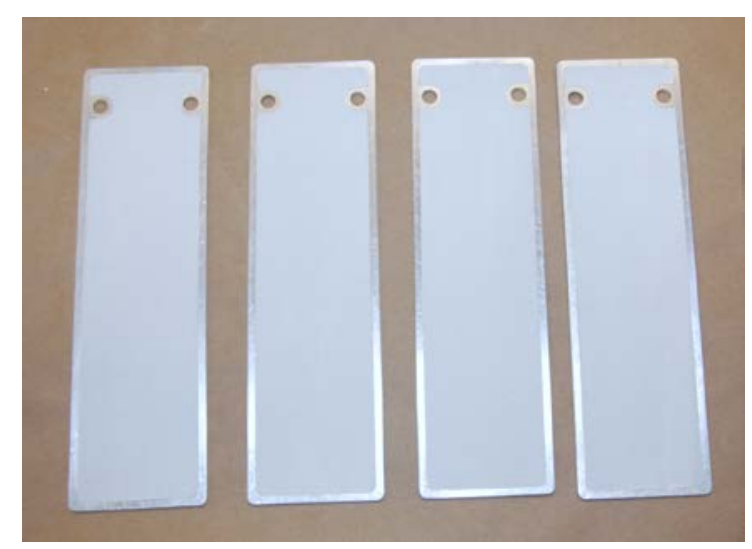

- One sample was exposed during each of the ATLAS TVAC tests (2 samples used total)

\begin{tabular}{|c|c|c|c|}
\hline TVAC TEST ID & CHAMBER ID & SAMPLE INSTALLATION & EXPOSURE TIME \\
\hline TVAC A & $\mathrm{X}$ & Mid 2017 & $\sim 50$ days \\
\hline TVAC B & $\mathrm{Y}$ & Late 2017 & $\sim 30$ days \\
\hline
\end{tabular}




\section{Sample Location}

- For each TVAC test, a MAC sample was installed in a strategic location that would best isolate and protect the critical laser flight optics during testing in the chamber facility

- The location of the MAC sample is identified by the white dashed rectangle as shown in the ATLAS thermal instrument model
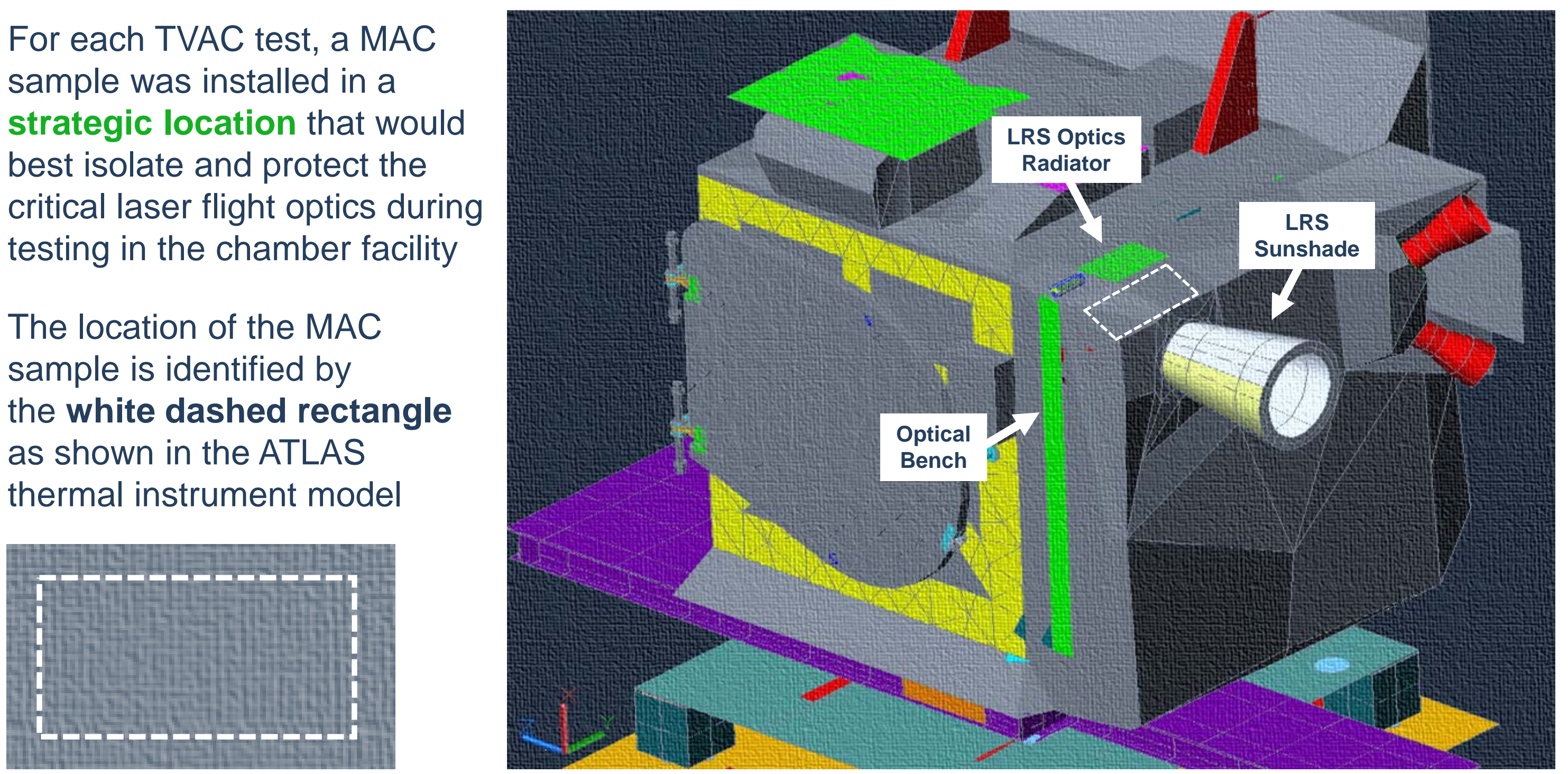


\section{Sample Location}

- The critical pathway for the transmit optics components on the optical bench is housed below the blanket vent (these components direct the laser from its source on the instrument)

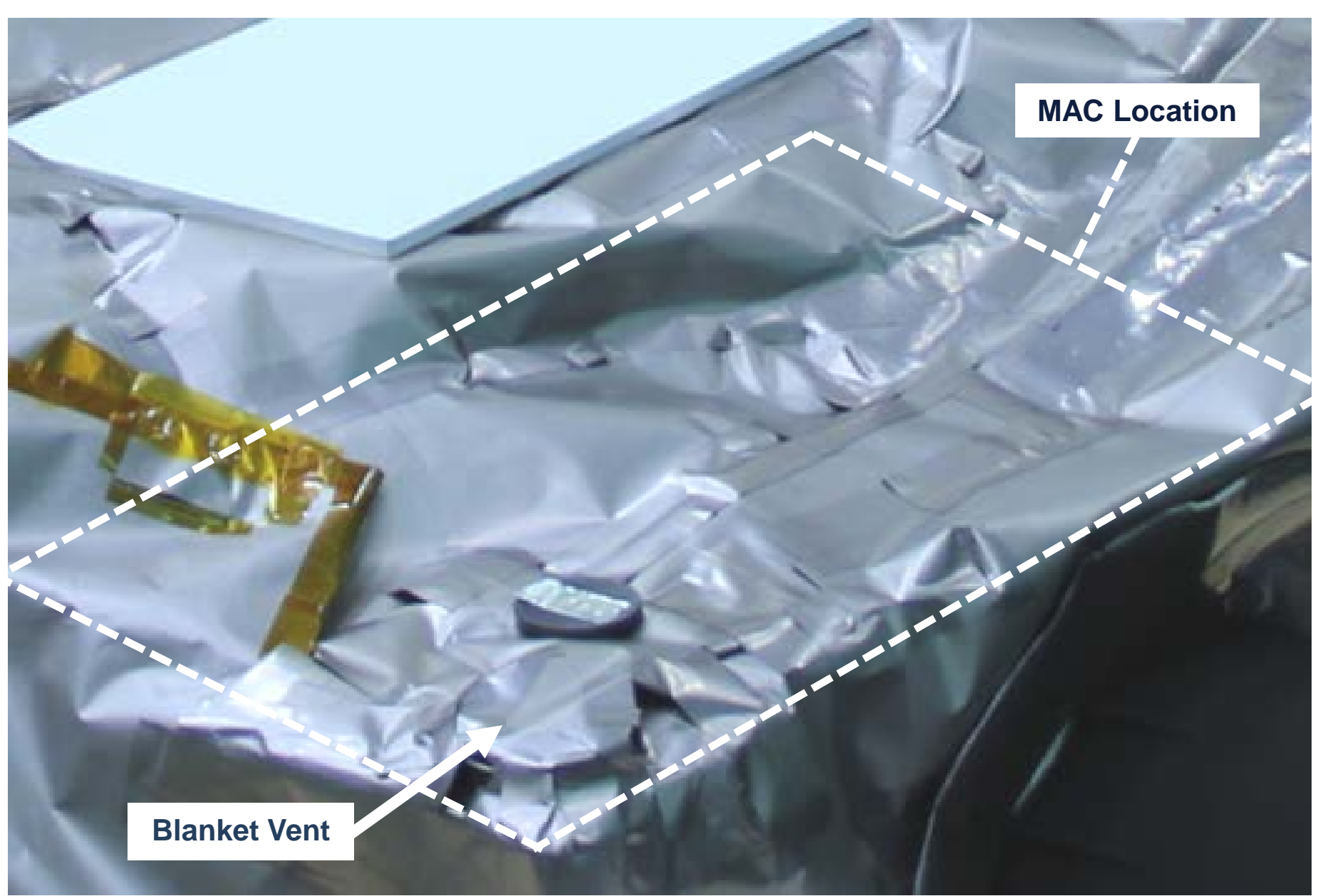

IMAGE CREDIT: NASA/GSFC

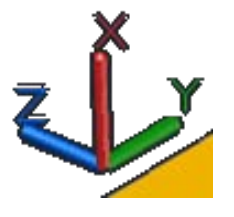




\section{Sample Configuration}

- An oval shaped blanket channel was constructed using VDA SLI material

- The purpose of the fabricated channel is to restrict the amount of outgassed species from the test environment that may contaminate the critical transmit optics along the vent path

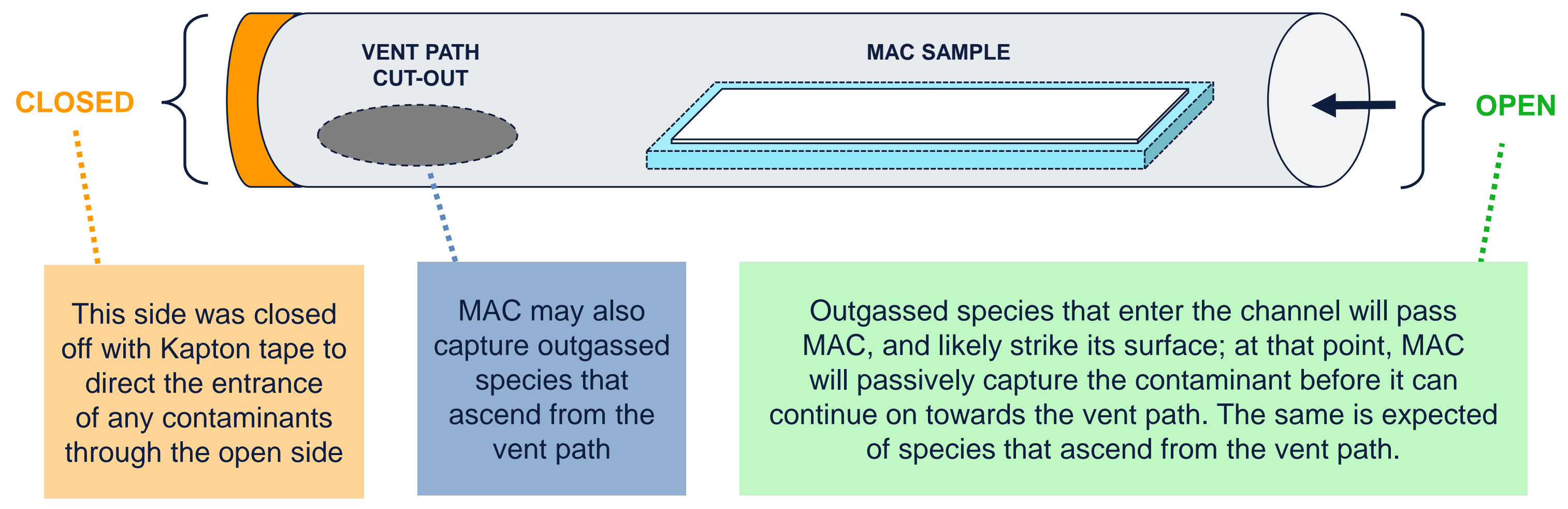




\section{Sample Configuration}

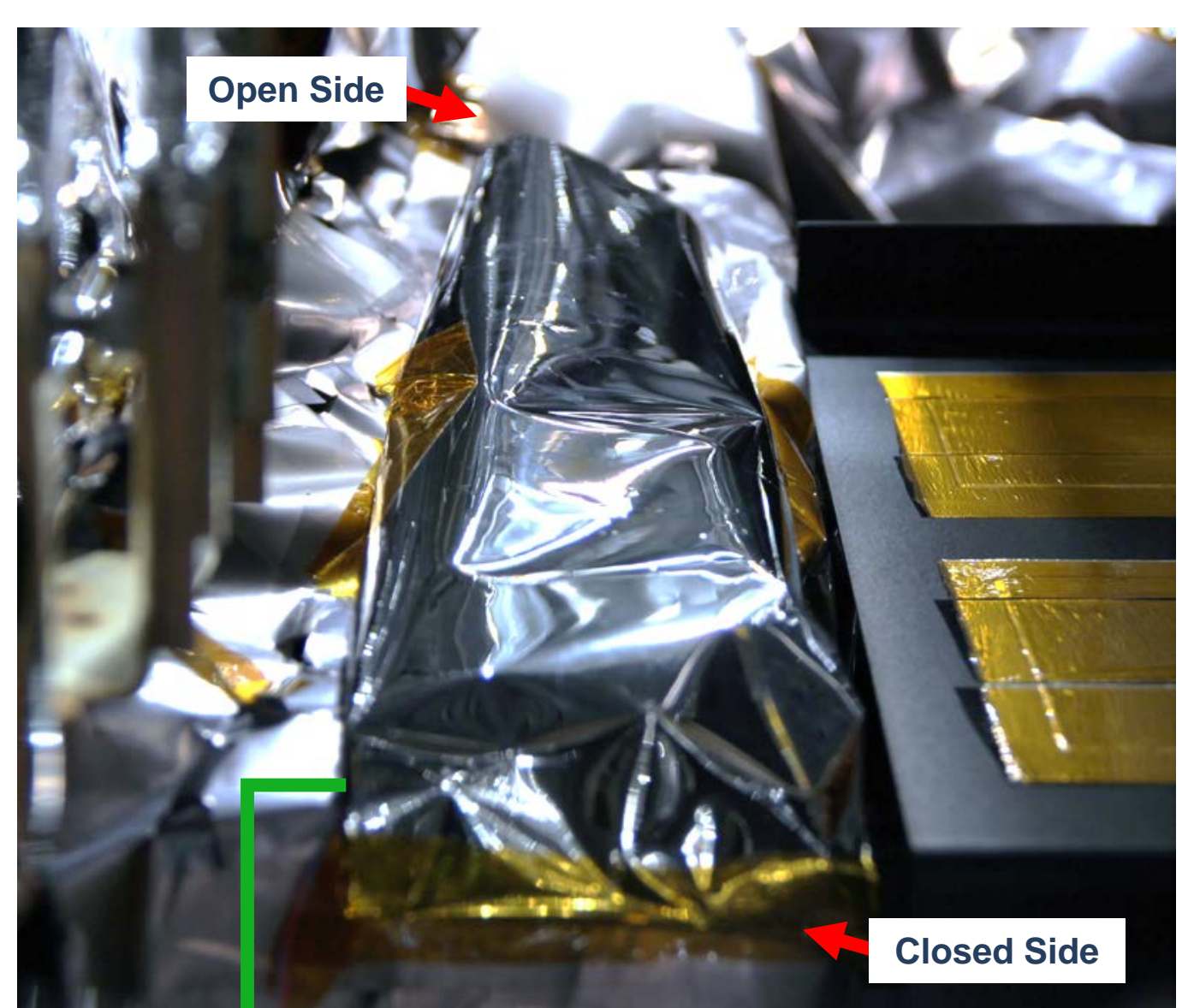

SAMPLE

ID

\section{SAMPLE}

ID

\section{INSTALLATION}

TVAC A

TVAC B

MAC \# 1

MAC \# 2

$\sim 30$ days TIME

-50 days

\section{EXPOSURE}

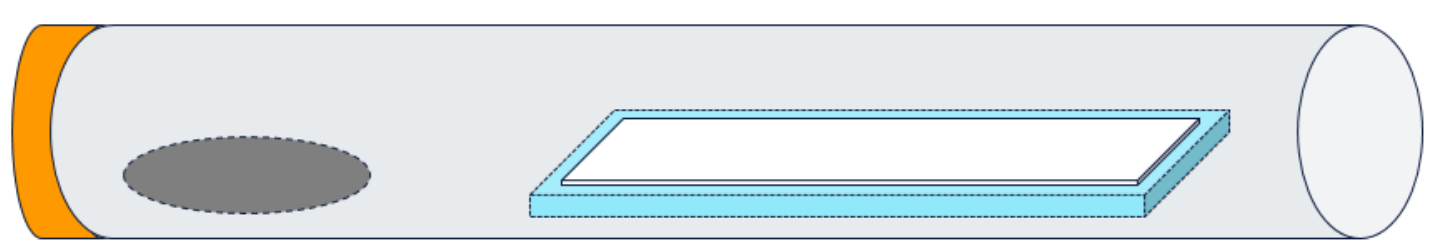

Shown is the blanket channel (with the MAC sample) installed prior to the start of TVAC B 


\section{Temperature Profile}

MAC \# 2 Sample Temperature Profile

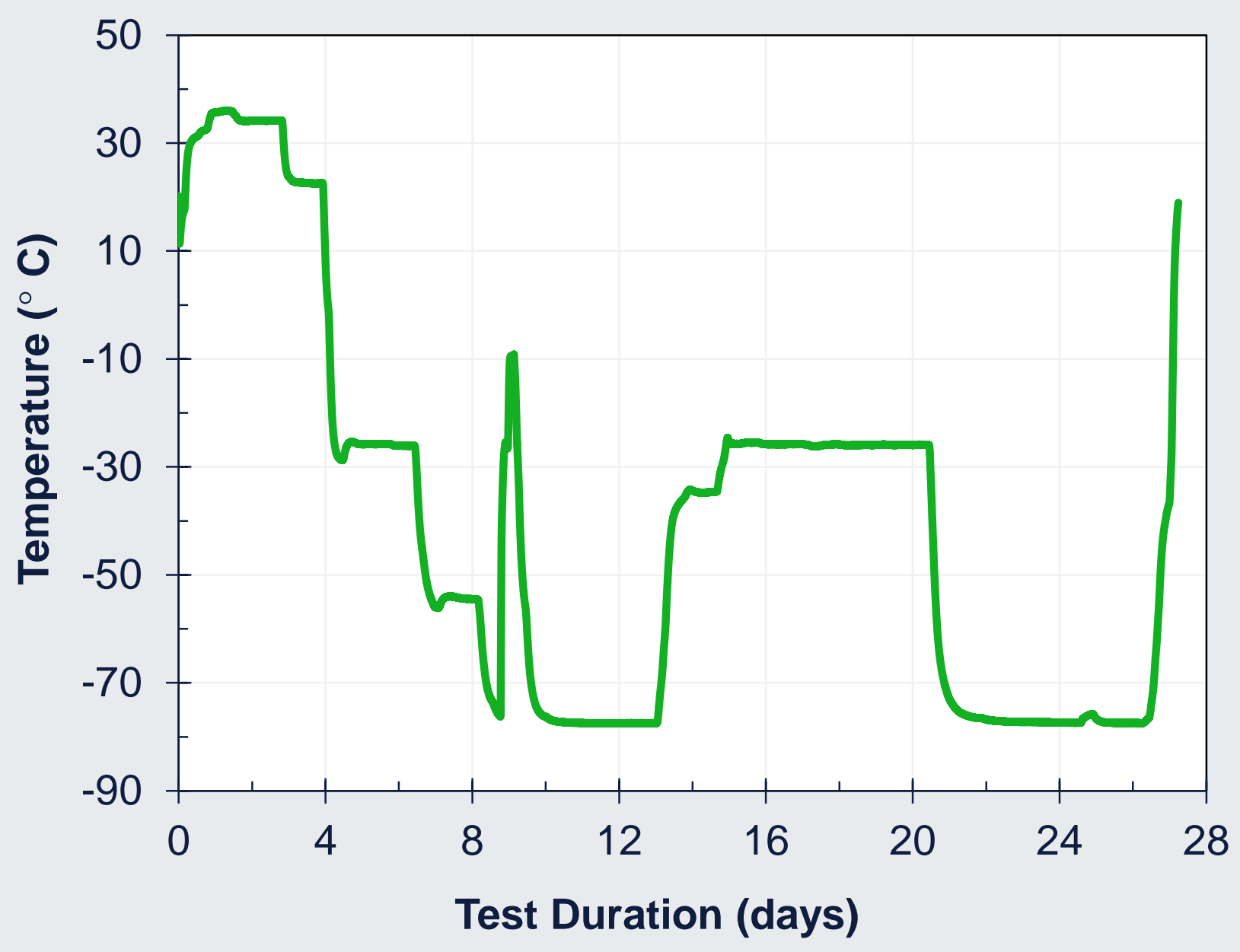

Maximum Temperature: $+36{ }^{\circ} \mathrm{C}$

Minimum Temperature: - $78{ }^{\circ} \mathrm{C}$

- A thermocouple was attached to monitor sample temperatures throughout the duration of the tests

- MAC \# 1 from TVAC A was exposed to a similar temperature profile

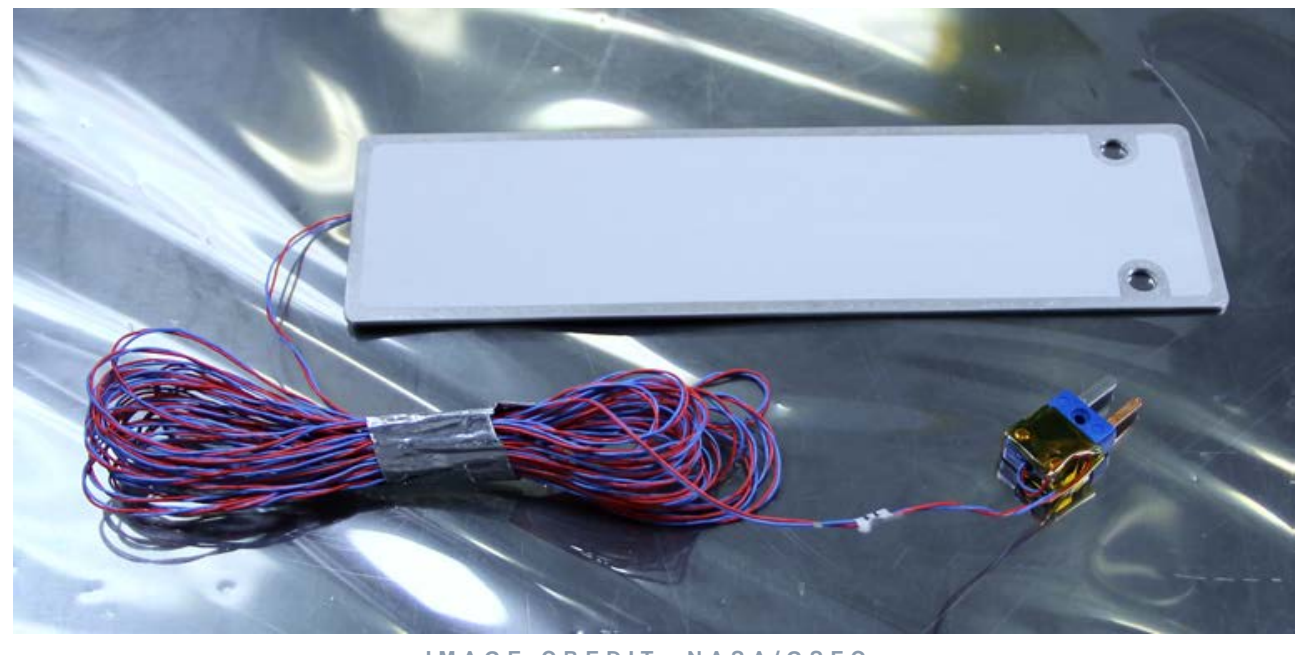




\section{Test Methods}

- Solvent Rinse Methods

- Chemical Analysis Methods 


\section{Solvent Rinse Methods}

- The surface of the coating was directly rinsed 4 times with optima grade chloroform

- This method was used to extract contaminants that were adsorbed on MAC - but only those that can be dissolved with the selected organic solvent

- Previous solvent rinse test efforts have demonstrated that:

- Chloroform is effective in dissolving common species of interest, such as hydrocarbons and silicones

- Multiple solvent rinses remove additional contaminants from MAC

- Dissolved species from multiple rinses decrease with each consecutive rinse

\section{MAC Control Sample}

- Coated at the same time as the other two

- Not exposed to any chamber facility

- Establishes a baseline reference

- Provides insight into the adsorbed residual contaminants due to handling or from exposure to offgassed species that are present in ambient, non-vacuum environments, such as a laboratory

\begin{tabular}{|c|c|c|c|}
\hline SAMPLE ID & $\begin{array}{c}\text { TVAC } \\
\text { EXPOSURE }\end{array}$ & $\begin{array}{c}\text { SAMPLE } \\
\text { CONDITION }\end{array}$ & ANALYSIS DATE \\
\hline MAC \# 0 & No TVAC & Control & August 2017 \\
\hline MAC \# 1 & TVAC A & Contaminated & August 2017 \\
\hline MAC \# 2 & TVAC B & Contaminated & March 2018 \\
\hline
\end{tabular}




\section{Solvent Rinse Methods}

\begin{tabular}{|c|c|c|c|c|}
\hline RINSE TYPE & TOTAL RINSES & RINSE NUMBER & RINSE SOLVENT \\
\hline Single & 1 & Rinse 1 & Chloroform \\
\hline Triple & 3 & Rinses 2, 3, 4 & Chloroform \\
\hline
\end{tabular}

\section{DETERMINING THE MASS OF THE NON-VOLATILE RESIDUE FROM THE SOLVENT RINSES}

Rinse sample 1x with solvent

Record mass of dishes to determine NVR
Collect 1x rinsate in pre-weighed dish

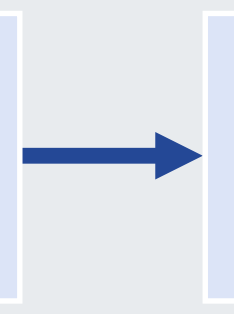

Rinse sample $3 x$ with solvent

Allow both to evaporate to dryness

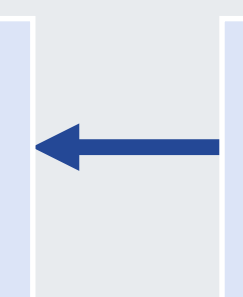

Collect 3x rinsate in another pre-weighed dish
Purpose of this multiple rinse $(3 x)$ is to dissolve any remaining contaminants in MAC 


\section{Chemical Analysis Methods}

- NVR from the samples were also evaluated using two chemical analysis methods to obtain a general approximation of the types and relative amounts of contaminants in the NVR

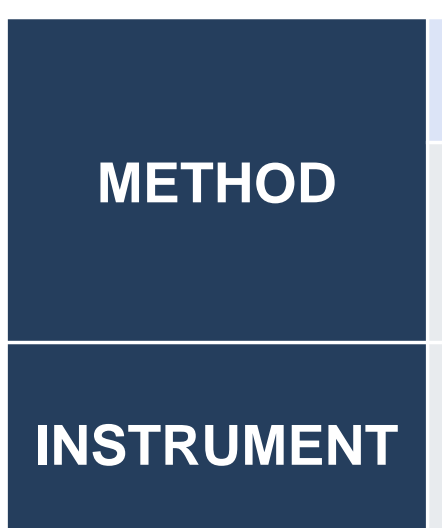

\section{FTIR ANALYSIS}

Fourier Transform Infrared Spectroscopy

Thermo Fisher Scientific Nicolet 6700

\section{PYROLYSIS GCIMS ANALYSIS}

\section{Pyrolysis-Gas Chromatography/Mass Spectrometry}

Shimadzu Scientific Instruments QP2010 Ultra and GL Sciences Optic-4 Inlet

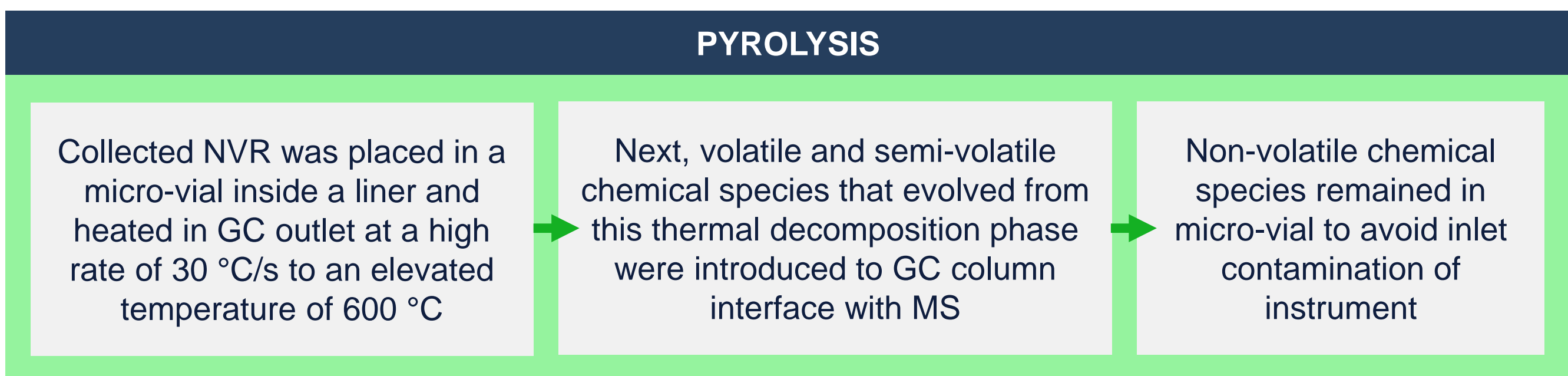




\section{Results \& Discussion}

- Solvent Rinse Results

- Molecular Adsorption Capacity

- Chemical Analysis Results

- Comparison to Contamination Monitoring Methods 


\section{Solvent Rinse Results}

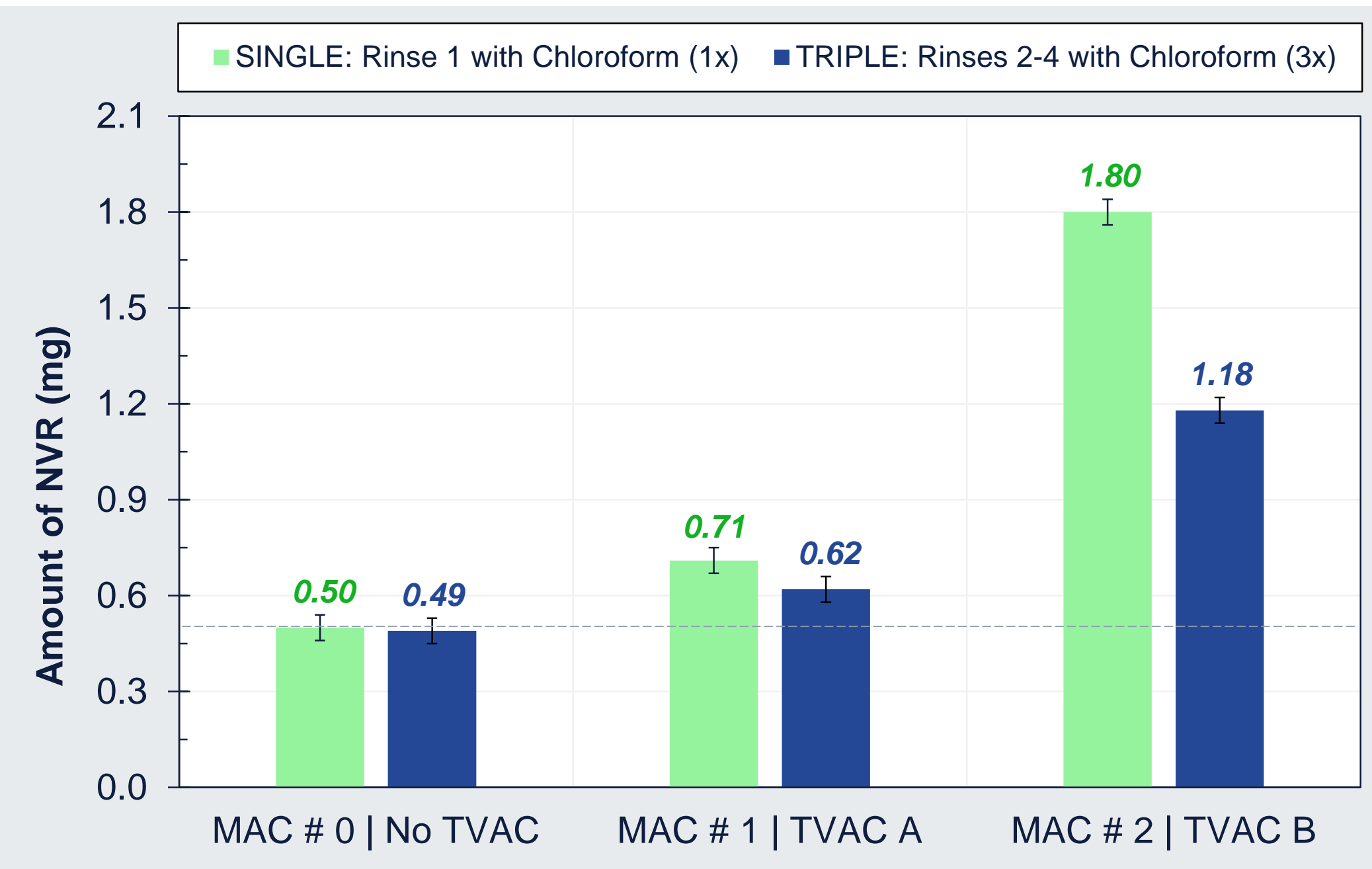

Sample ID and TVAC Exposure

\section{SINGLE RINSE}

\begin{tabular}{|c|c|}
\hline TEST ID & ADJUSTED NVR \\
\hline TVAC A & $0.21 \mathrm{mg}$ \\
\hline TVAC B & $1.30 \mathrm{mg}$ \\
\hline The control sample was subtracted for the adjusted NVR shown
\end{tabular}

- Amount collected during TVAC B was about $\mathbf{6 . 2}$ times greater than TVAC A

- Similar trends were observed for $3 x$ rinse runs of exposed TVAC samples

- Decreasing NVR for 3x rinse suggests that most of the contaminants were removed in the initial $1 x$ rinse 


\section{Solvent Rinse Results}

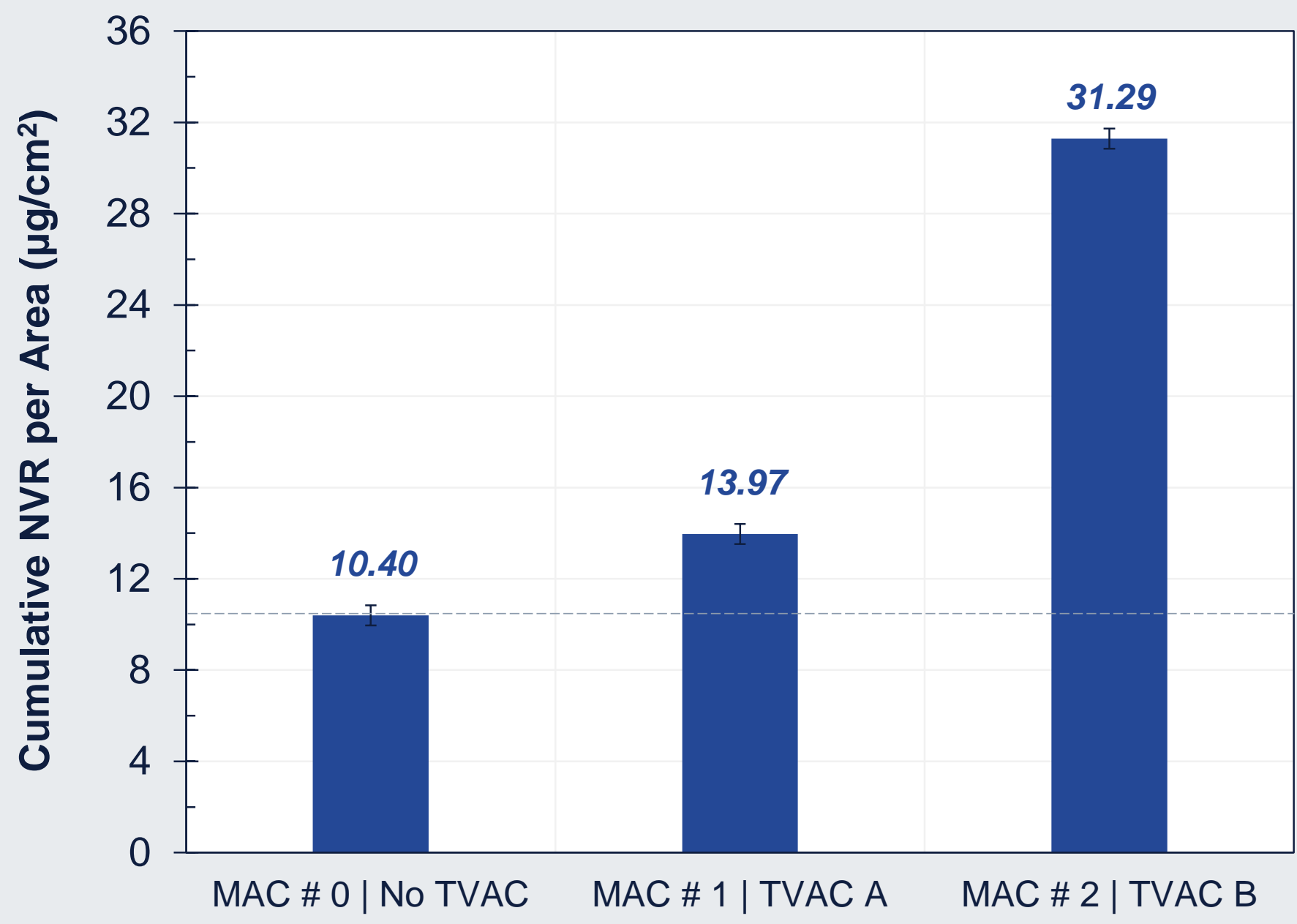

Sample ID and TVAC Exposure

\section{SAMPLE ID}

MAC \# 0

MAC \# 1

MAC \# 2

\section{CUMULATIVE NVR}

- Sample exposed during TVAC B captured the most contaminants, even though, it was exposed for a shorter test duration

- Some possible reasons for this may include differences in the test facility, chamber size, temperature variations, and sample handling procedures

- MAC \# 2 results are about:

- 3 times greater than control sample

- 2.3 times greater than MAC \#1 


\section{Molecular Adsorption Capacity}

- Past studies have involved saturating MAC samples with stearyl alcohol as the test contaminant source under vacuum conditions

- Stearyl alcohol is an 18-chain hydrocarbon that is representative of outgassed species that are commonly found in spaceflight applications

- The experimental data shown suggests that the molecular adsorption capacity of MAC is directly proportional to coating thickness

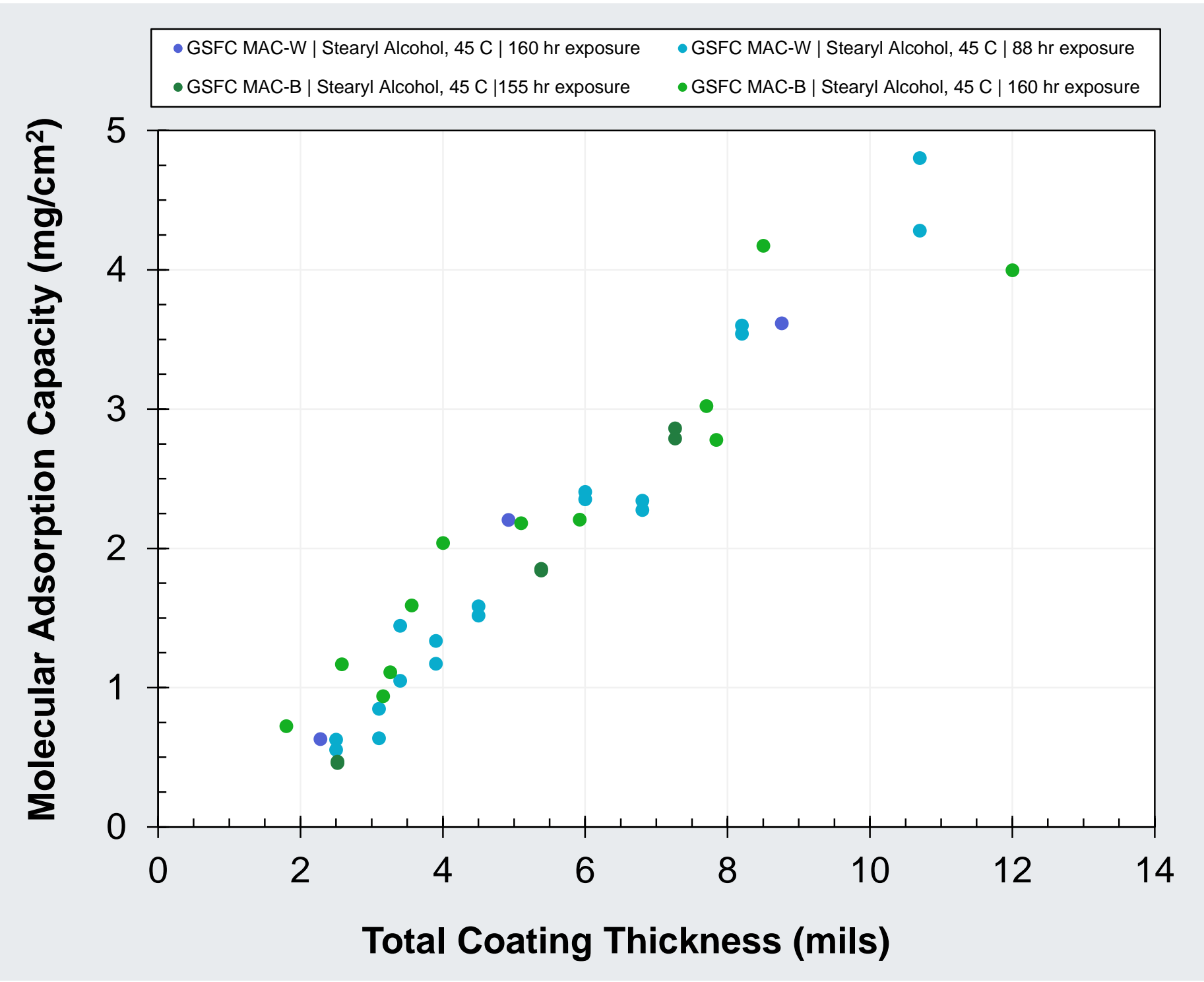




\section{Molecular Adsorption Capacity}

- The predicted vacuum molecular adsorption properties of the MAC samples that were used during the ATLAS TVAC tests are shown below:

\begin{tabular}{|c|c|}
\hline Coating Thickness & 6.2 mils \\
\hline Coating Area & $95.2 \mathrm{~cm}^{2}$ \\
\hline $\begin{array}{c}\text { Estimated Molecular } \\
\text { Adsorption Capacity } \\
\text { in Vacuum }\end{array}$ & $2.4 \mathrm{mg} / \mathrm{cm}^{2}$ \\
\hline $\begin{array}{c}\text { Estimated } \\
\text { Maximum Mass }\end{array}$ & $\sim 228 \mathrm{mg}$ \\
\hline $\begin{array}{c}\text { However, this assumes that } \\
\text { the majority of the species } \\
\text { collected during the tests are } \\
\text { long-chain hydrocarbons } \\
\text { similar to stearyl alcohol }\end{array}$
\end{tabular}

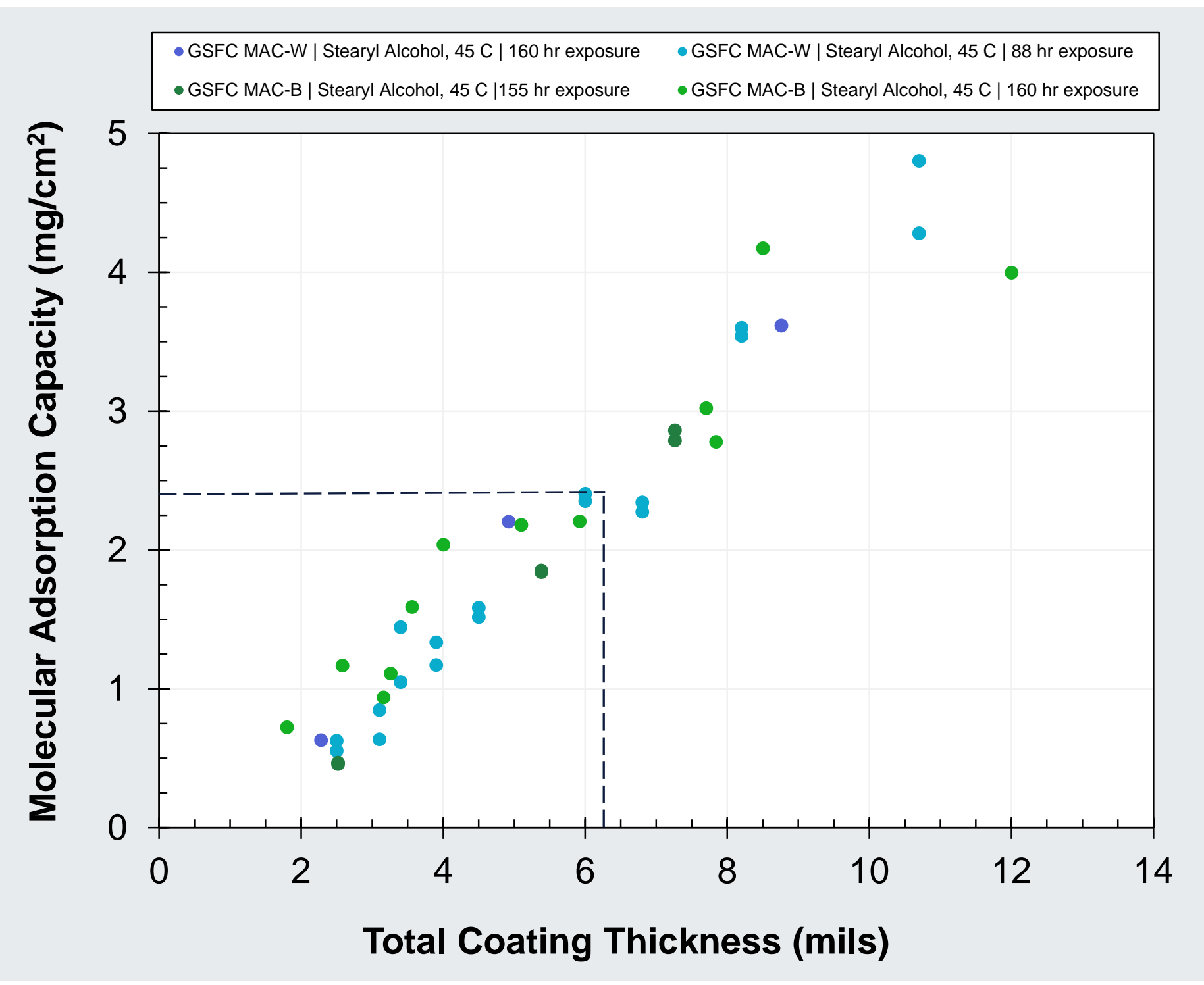




\section{Molecular Adsorption Capacity}

- The saturation ratio is defined as the ratio of the cumulative NVR per coating area to the estimated experimental molecular adsorption capacity (in vacuum conditions)

- The results suggest that the MAC samples that were deployed during the TVAC tests were not significantly contaminated with outgassed species to complete saturation of the pores in the coating

- Nevertheless, the chemical species that were collected during TVAC were isolated from further contaminating the critical laser flight optics on the ATLAS instrument

\section{SAMPLE}

\section{ESTIMATED SATURATION RATIO}

MAC \# 1

$0.6 \%$

MAC \# 2

$1.3 \%$

\section{SOME CONSIDERATIONS}

- Not all of the adsorbed contaminants will be removed with multiple solvent rinses

- Not all of the adsorbed contaminants will be long-chain hydrocarbons similar to the experiment contaminant 


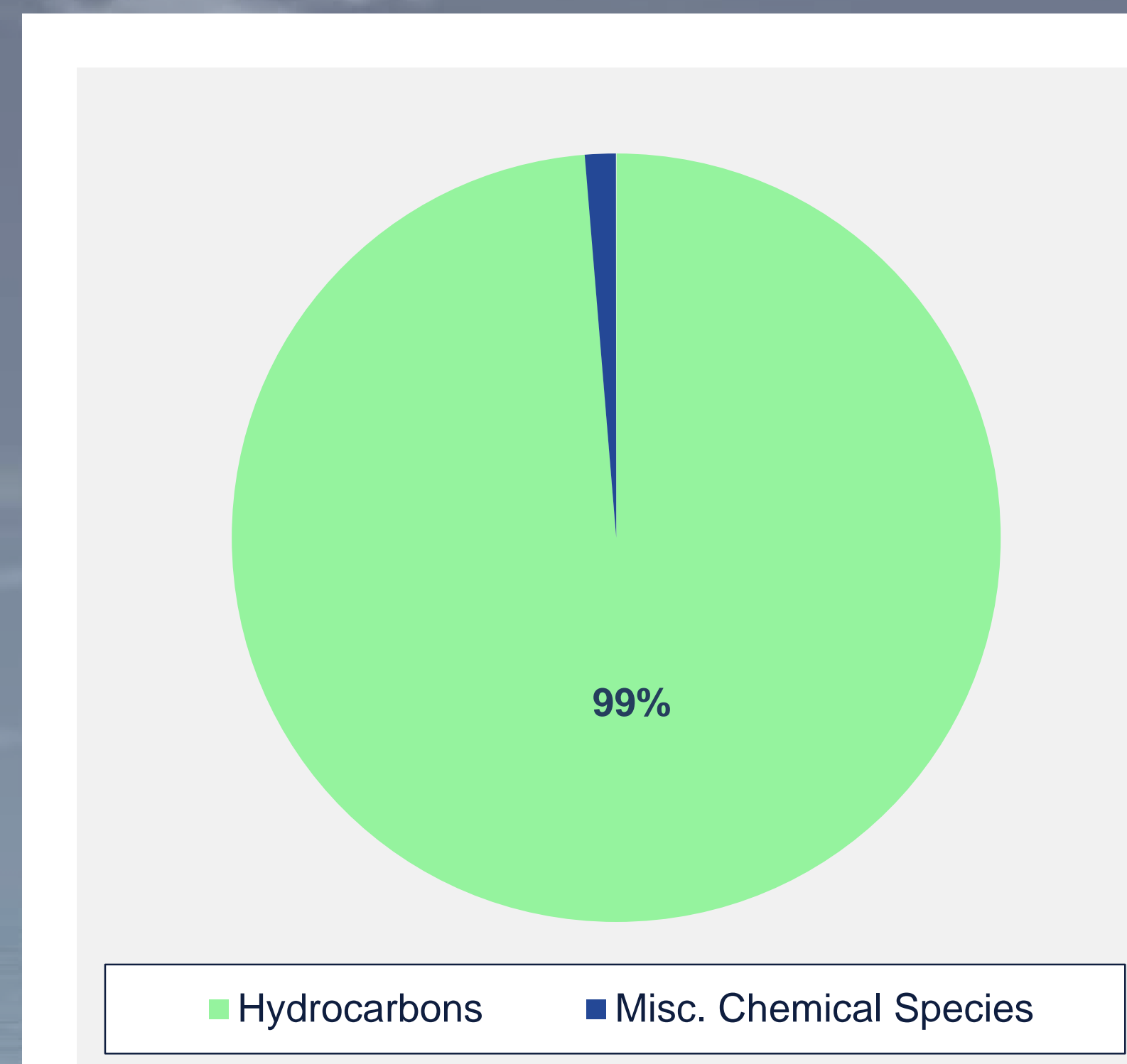

\section{MAC \# 0 Control Sample}

- Shown is the percent distribution of chemical species for the single solvent rinse of the control sample

- Results indicate that $99 \%$ is comprised of primarily hydrocarbons that may have been adsorbed from exposure to the ambient environment during its storage period or due to sample handling

- Remaining $1 \%$ of miscellaneous species are likely room environmental compounds

- Similar trends were observed for $3 x$ rinse of control sample (as well as the two vacuum exposed samples) 


\section{Chemical Analysis Results}

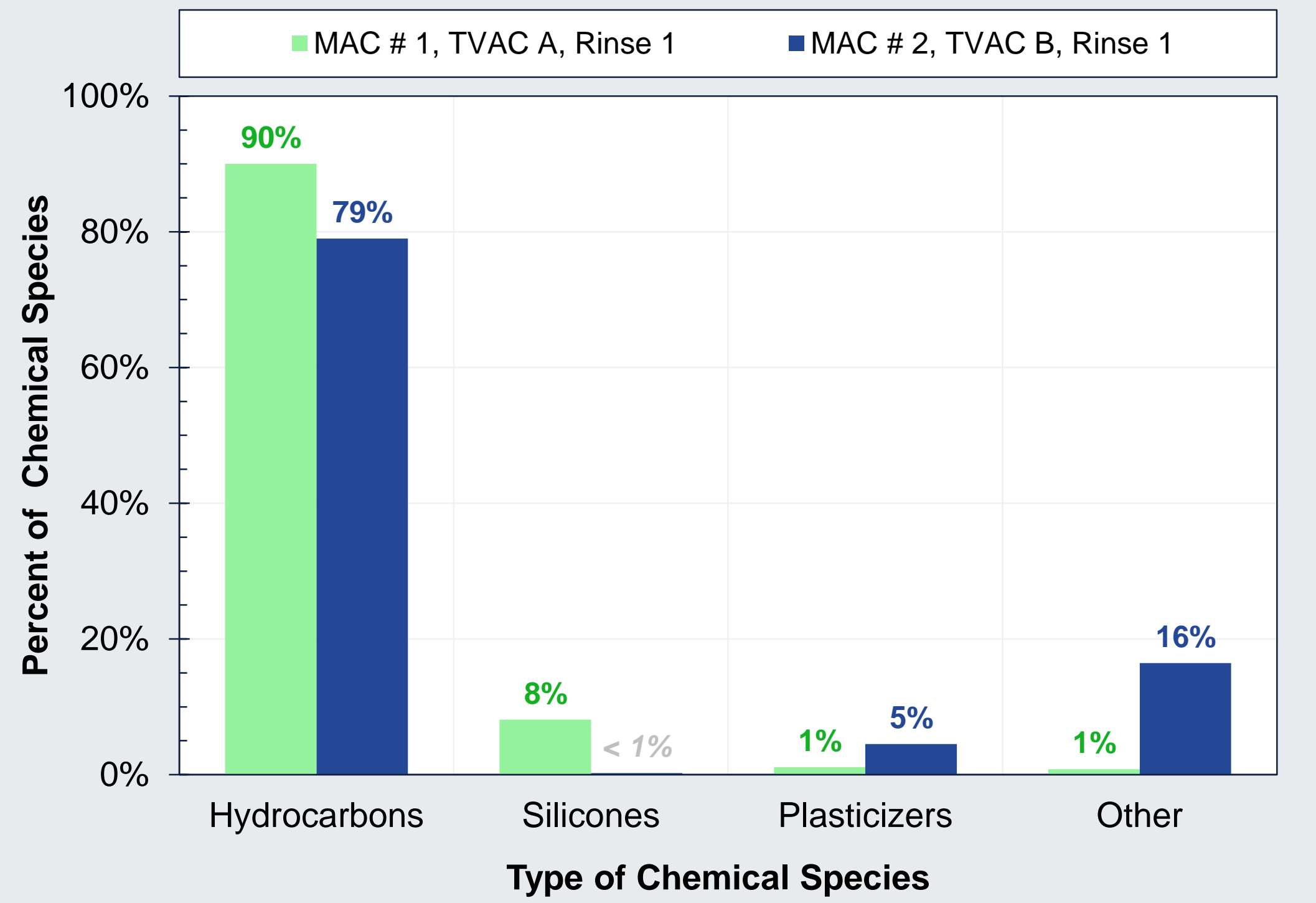

\section{Both TVAC Tests}

- Most abundant type of chemical species were hydrocarbons

\section{TVAC A}

- Second most abundant species at $8 \%$ were silicones, such as methyl phenyl silicones and methyl silicones, that are commonly sourced from lubricants, elastomers, and adhesives

- Remaining least abundant species at $2 \%$ consisted of plasticizers, such as phthalate-based species, and other miscellaneous chemical constituents, such as palmitate-based species 


\section{Chemical Analysis Results}

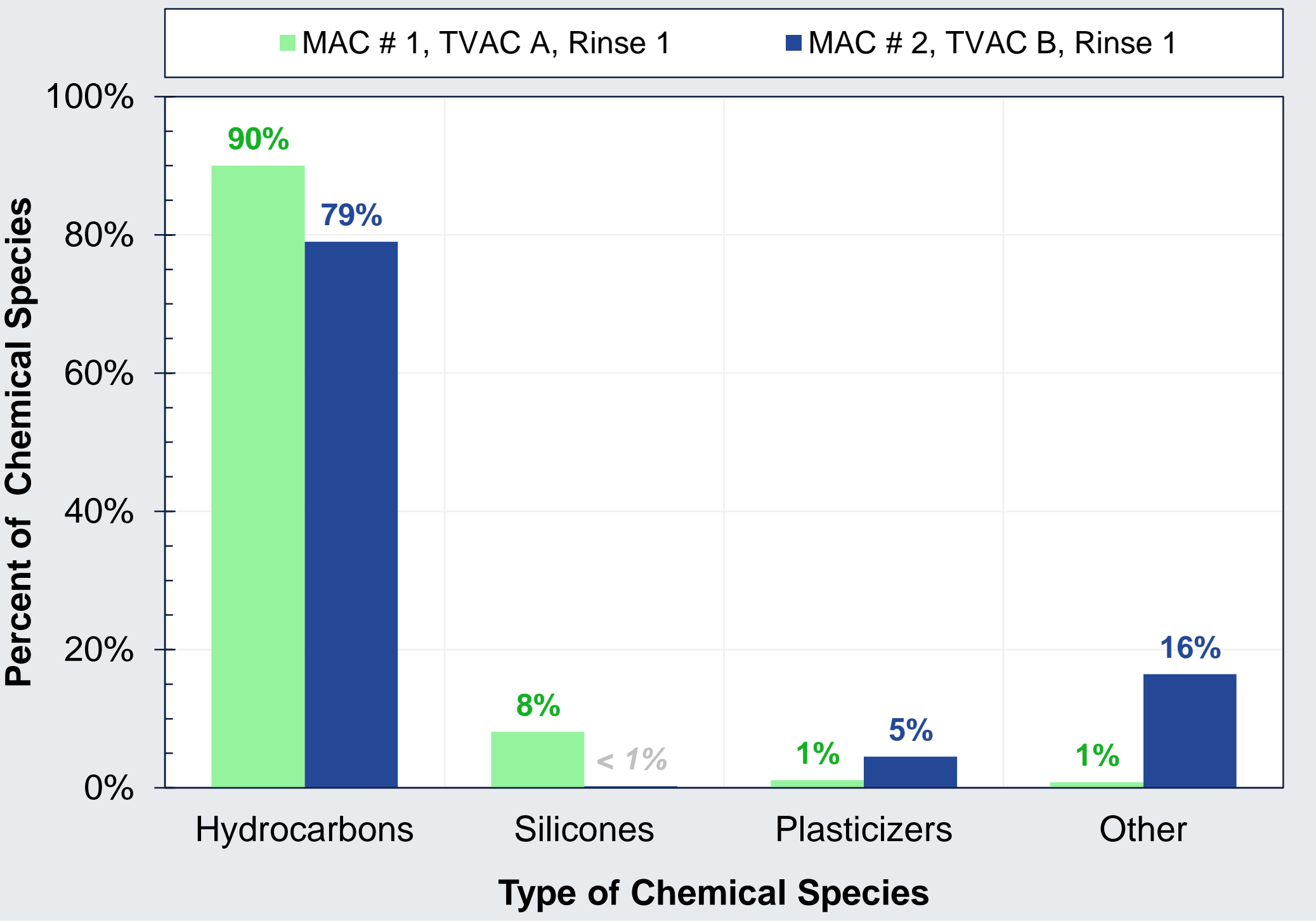

\section{TVAC B}

- Second most abundant species were "other" at $16 \%$, specifically handling contaminants, which consisted of mostly palmitatebased species, such as isopropyl palmitate, which are commonly found in cosmetics (i.e. emollients, moisturizers, thickening agents), lubricants, rubber, and latex

- "Other" also included methyl palmitate, butyl palmitate, and isopropyl myristate

- Third most abundant species at $5 \%$ include phthalate-based plasticizers, such as di(2ethylhexyl) phthalate

- Least abundant species identified were silicone-based compounds at $0.2 \%$ 


\section{Chemical Analysis Results}

MAC \# 0 Rinse 1

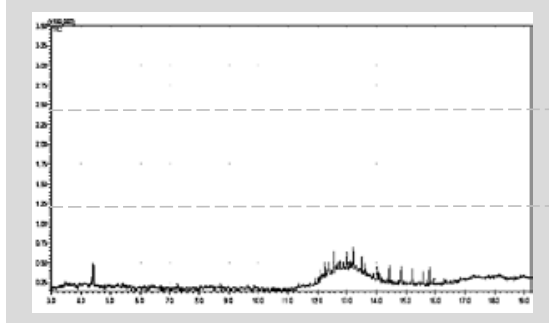

\section{MAC \# 1 Rinse 1}
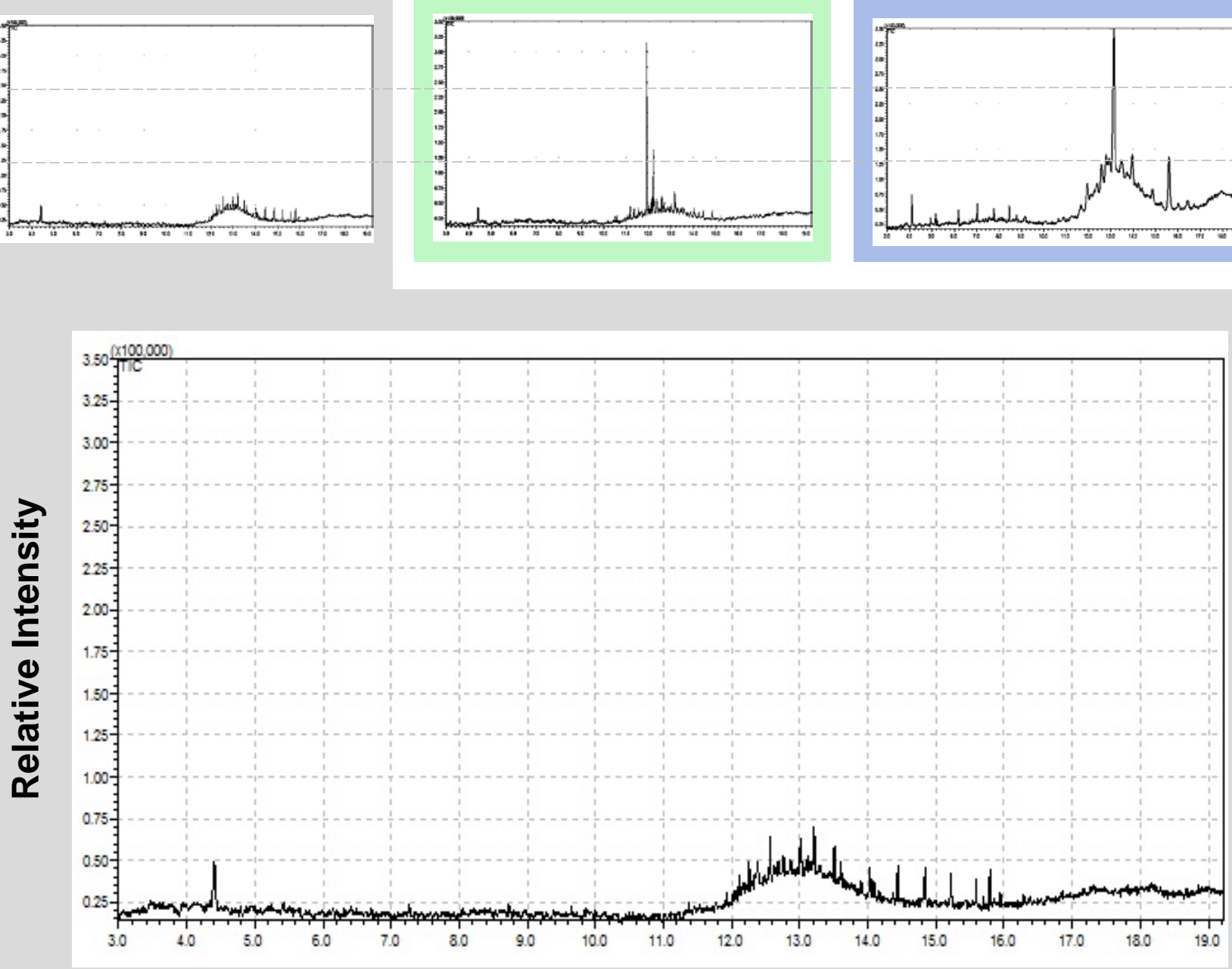

Retention Time (min)

\section{MAC \# 2 Rinse 1}

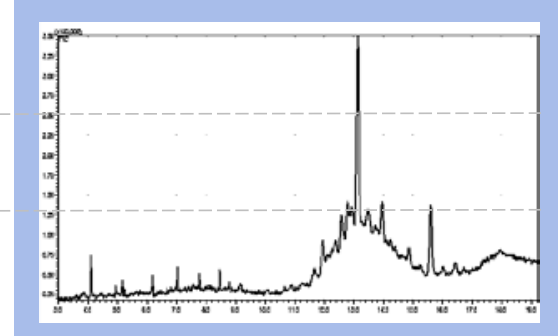

- Mostly hydrocarbon peaks
- GC/MS plot shows the lowest relative intensity, or compound abundance, of identified species 


\section{Chemical Analysis Results}

MAC \# 0 Rinse 1

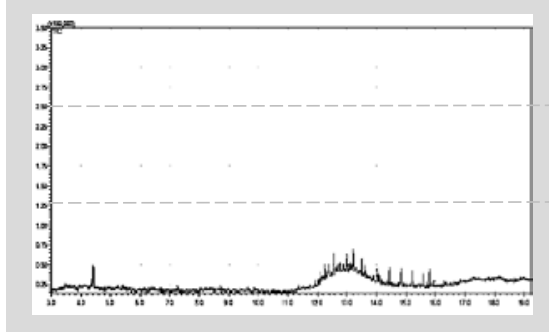

MAC \# 1 Rinse 1

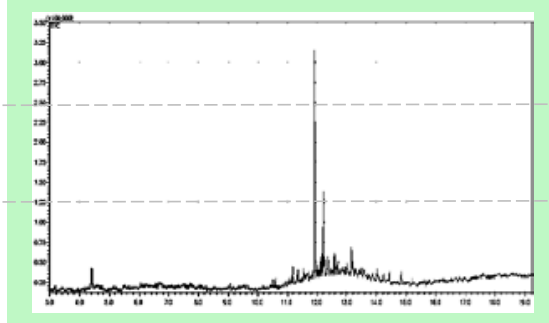

MAC \# 2 Rinse 1
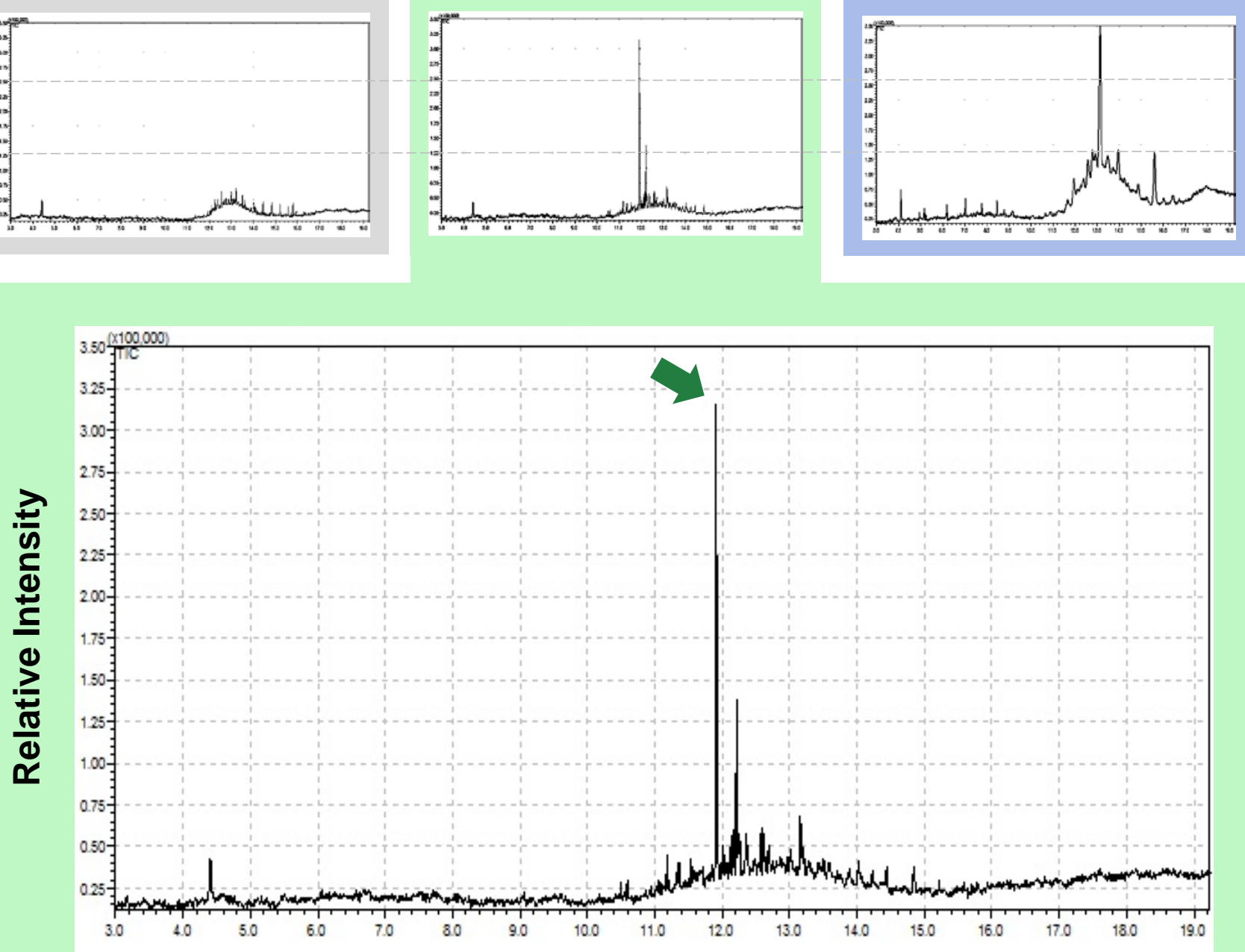

Retention Time (min)

\section{MAC \# 1 from TVAC A}

- GC/MS plot shows additional peaks at a greater relative intensity when compared to the control sample

- Mostly hydrocarbon peaks

- Highest intensity peak present for silicones, such as methyl phenol silicone at around $11.9 \mathrm{~min}$ 


\section{Chemical Analysis Results}

MAC \# $0 \quad$ Rinse 1
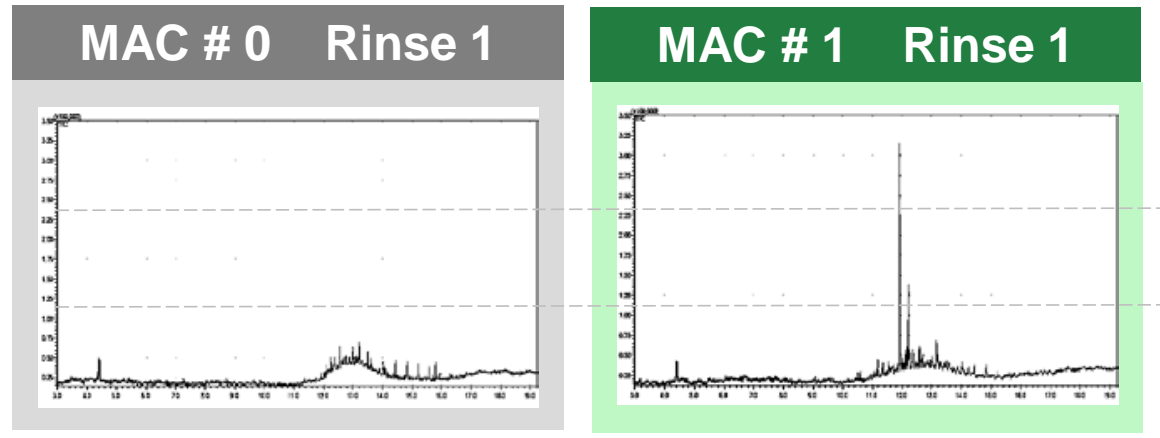

\section{MAC \# 2 Rinse 1}
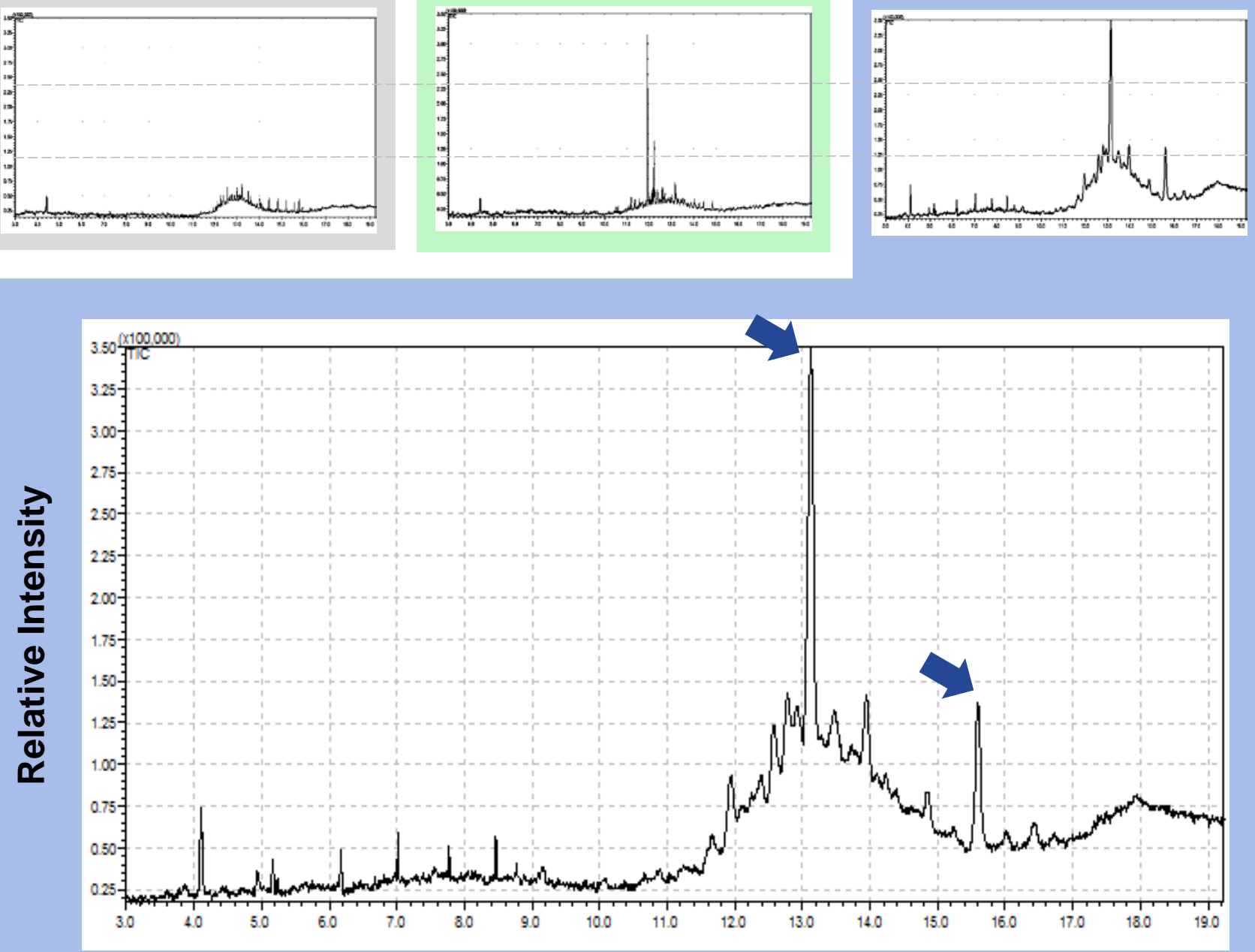

Retention Time (min)

\section{MAC \# 2 from TVAC B}

- GC/MS plot shows the greatest relative intensity of species when compared to control sample and first TVAC sample

- Again, mostly hydrocarbon peaks

- Many high intensity peaks present for palmitate-based species, such as isopropyl palmitate at around 13.2 min

- High intensity peaks also present for plasticizers, such as di(2-ethylhexyl) phthalate at around $15.6 \mathrm{~min}$ 


\section{Comparison to Contamination Monitoring Methods}

- MAC results were compared against typical contamination control monitoring methods, which are often used during spaceflight vacuum chamber testing

\begin{tabular}{|c|c|c|c|}
\hline Monitoring Method & Witness Foil & Scavenger Plate & Cold Finger \\
\hline Description & Witness Sample & Cold panel cooled by LN2 & $\begin{array}{l}\text { Small cylindrical device } \\
\text { cooled by LN2 }\end{array}$ \\
\hline Purpose & $\begin{array}{l}\text { Used to collect NVR } \\
\text { representative of what may } \\
\text { be found on the hardware }\end{array}$ & $\begin{array}{c}\text { Used to collect the } \\
\text { majority of the outgassed } \\
\text { contamination throughout } \\
\text { the TVAC test }\end{array}$ & $\begin{array}{l}\text { Used to collect residual } \\
\text { outgassing during } \\
\text { the last several hours } \\
\text { of the TVAC test }\end{array}$ \\
\hline NVR Rinse & Chloroform & Isopropyl Alcohol & Isopropyl Alcohol \\
\hline Chemical Analysis & FTIR \& GC/MS & FTIR \& GC/MS & FTIR \& GC/MS \\
\hline
\end{tabular}




\section{Comparison to Contamination Monitoring Methods}

- Comparison provides additional verification of the identified contaminant species from the MAC samples that were installed for the two TVAC tests

\begin{tabular}{|c|c|c|c|c|c|c|c|c|}
\hline & \multicolumn{3}{|c|}{ TVAC A } & \multicolumn{5}{|c|}{ TVAC B } \\
\hline & $\begin{array}{c}\text { MAC } \\
\text { Sample }\end{array}$ & $\begin{array}{c}\text { TVAC } \\
\text { Witness } \\
\text { Foil }\end{array}$ & $\begin{array}{c}\text { TVAC } \\
\text { Scavenger } \\
\text { Plate }\end{array}$ & $\begin{array}{c}\text { MAC } \\
\text { Sample }\end{array}$ & $\begin{array}{c}\text { TVAC } \\
\text { Witness } \\
\text { Foil }\end{array}$ & $\begin{array}{c}\text { TVAC } \\
\text { Bake-Out } \\
\text { Scavenger } \\
\text { Plate }\end{array}$ & $\begin{array}{l}\text { TVAC } \\
\text { Bake-Out } \\
\text { Cold } \\
\text { Finger }\end{array}$ & $\begin{array}{c}\text { Post TVAC } \\
\text { Chamber } \\
\text { Cert Cold } \\
\text { Finger }\end{array}$ \\
\hline & Chloroform & Chloroform & $\begin{array}{c}\text { Isopropyl } \\
\text { Alcohol }\end{array}$ & Chloroform & Chloroform & $\begin{array}{l}\text { Isopropyl } \\
\text { Alcohol }\end{array}$ & $\begin{array}{l}\text { Isopropyl } \\
\text { Alcohol }\end{array}$ & $\begin{array}{l}\text { Isopropyl } \\
\text { Alcohol }\end{array}$ \\
\hline Hydrocarbons & $X$ & $X$ & $x$ & $X$ & & $x$ & $X$ & $X$ \\
\hline Silicones & $X$ & $x$ & $x$ & $X$ & $X$ & $x$ & $X$ & \\
\hline Plasticizers & $x$ & $x$ & $x$ & $X$ & $x$ & $X$ & 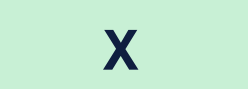 & $X$ \\
\hline Other & $X$ & $X$ & & $X$ & $x$ & $x$ & $X$ & $X$ \\
\hline
\end{tabular}




\section{Comparison to Contamination Monitoring Methods}

- A solvent rinse NVR comparison was made between the witness foils and the MAC samples given that they are both passive collection methods

- Witness foils were deployed during the start of each test and placed in a subject location near the ATLAS instrument in the chamber facility; however, the MAC samples and witness foils were not installed in the same location

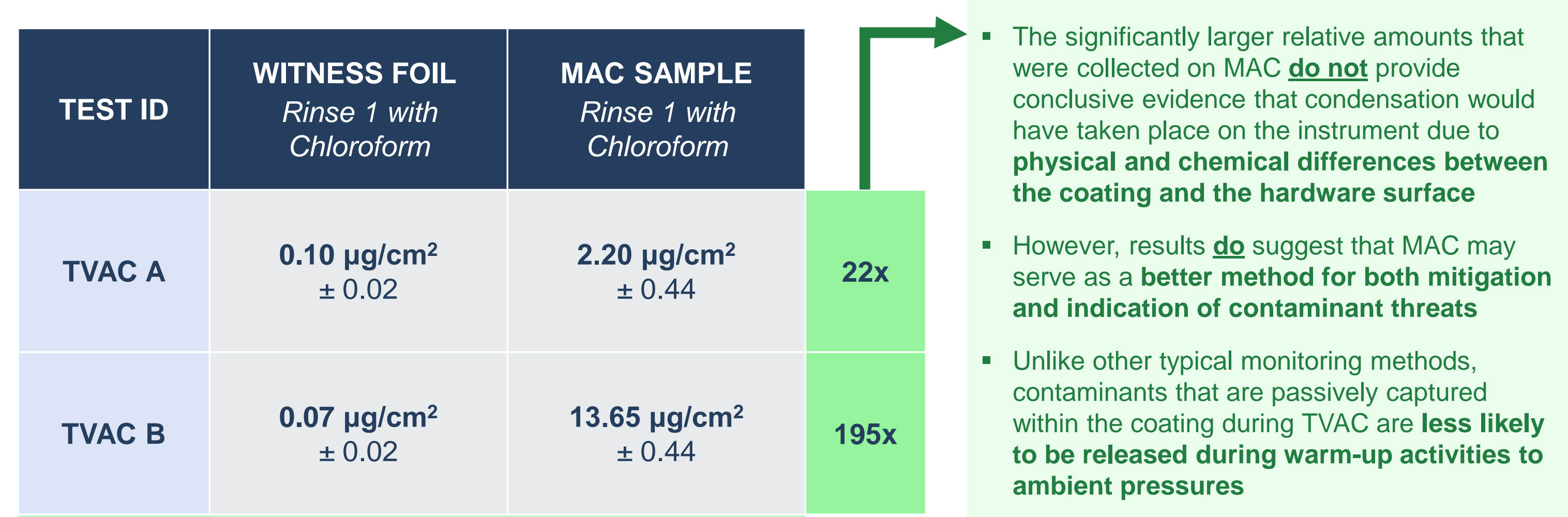




\section{Summary}

- Conclusions

- Future Work 


\section{Conclusions}

- The use of the MAC technology during ATLAS TVAC testing was effective in protecting the critical laser flight optics

- The identified chemical species that were captured by MAC isolated the transmit optics components from potential molecular contamination

- The continued use of the MAC technology as both a mitigator and indicator for outgassed molecular contaminants is recommended during vacuum chamber tests of spaceflight hardware for future NASA missions

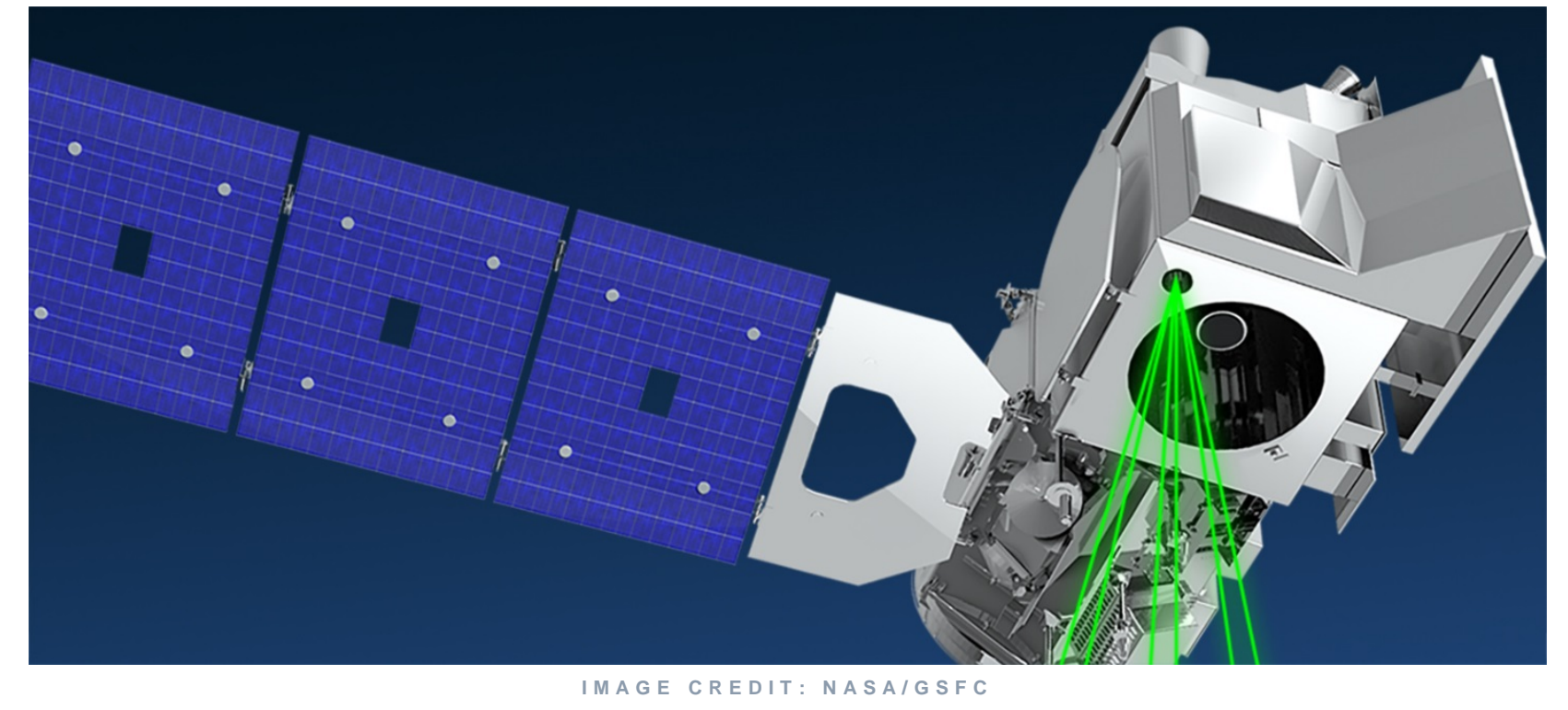

\section{FUTURE WORK}

- Explore alternative methods of identifying the collected contaminants on MAC, such as via thermal desorption techniques or the use of other organic solvents 


\section{Questions?}

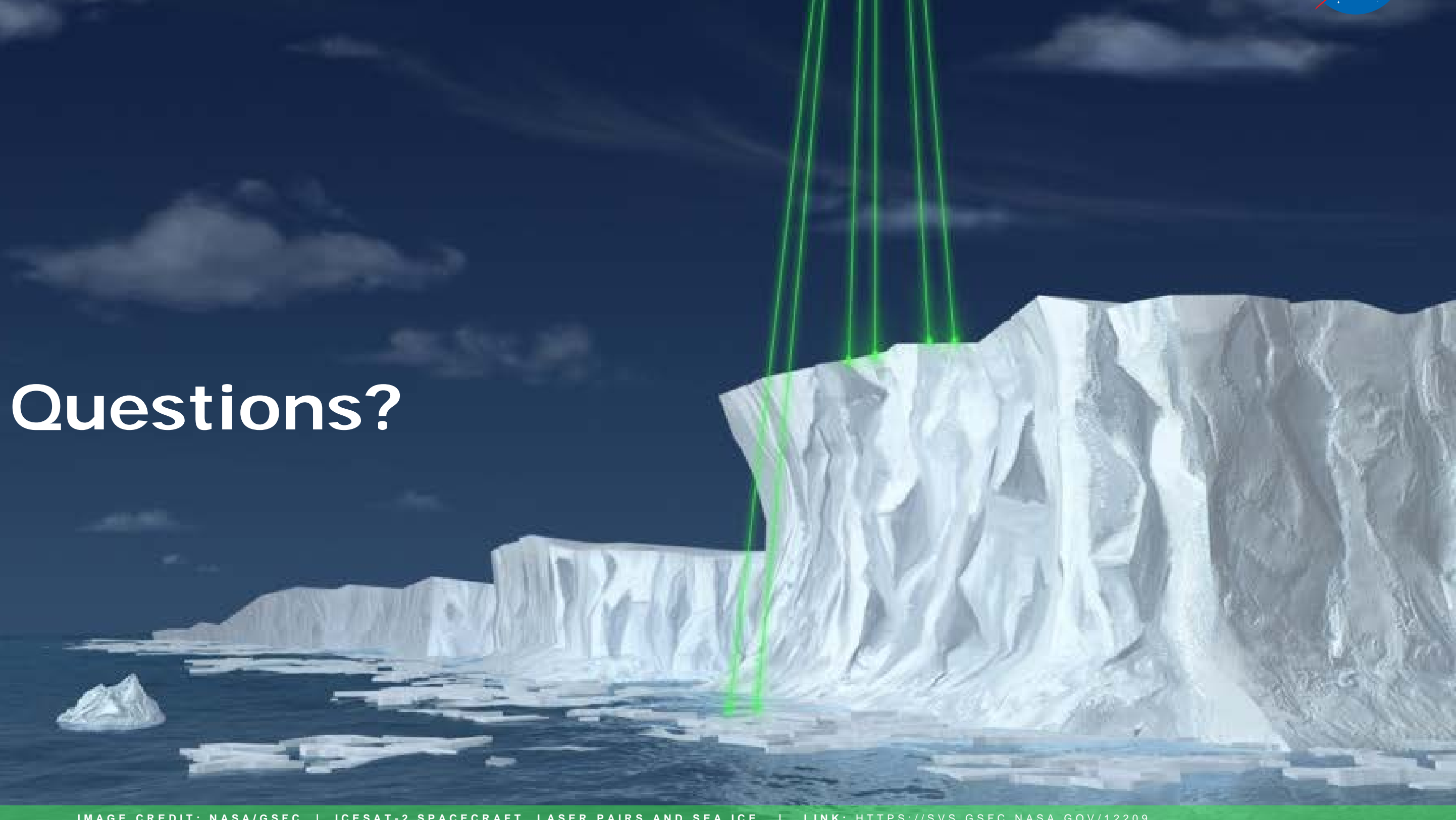




\section{Acronyms}

- ATLAs

- fTIR

- FUV

- GC/MS

- GEDI

- GOLD

- GSFC

- I\&T

- ICESat-2

- ICON

- JWST

- LN2

- LRS

- MAC

- MAC-W

- MMS

- NASA

- NICER

- NVR

- OgSE

- OTIS

- SGT

- SLI

- TPF

- tVAc

- VDA
Advanced Topographic Laser Altimeter System

Fourier Transform Infrared Spectroscopy

Far Ultraviolet

Gas Chromatography/Mass Spectrometry

Global Ecosystem Dynamics Investigation Lidar

Global-scale Observations of the Limb and Disk

Goddard Space Flight Center

Integration and Test

Ice, Cloud, and Land Elevation Satellite 2

Ionospheric Connection Explorer

James Webb Space Telescope

Liquid Nitrogen

Laser Reference System

Molecular Adsorber Coating

White Molecular Adsorber Coating

Magnetosphere Multiscale Mission

National Aeronautics and Space Administration

Neutron star Interior Composition Explorer

Non-Volatile Residue

Optical Ground Support Equipment

Optical Telescope Element And Integrated Science

Stinger Ghaffarian Technologies

Single Layer Installation

Thermal Pathfinder

Thermal Vacuum

Vapor Deposited Aluminum 


\section{References}

1. National Aeronautics and Space Administration, "ICESat2: Fact Sheet", Accessed 1 June 2018, <https://icesat2.gsfc.nasa.gov/sites/default/files/page_files/ICESat$2 \% 20$ Fact $\% 20$ Sheet.pdf>

2. National Aeronautics and Space Administration, "ICESat2: How It Works", Accessed 1 June 2018, <https://icesat2.gsfc.nasa.gov/how-it-works>

3. National Aeronautics and Space Administration, "ICESat2: Space Lasers", Accessed 1 June 2018 <https://icesat-2.gsfc.nasa.gov/space-lasers>

4. National Aeronautics and Space Administration, "ICESat2: Technical Specs", Accessed 1 June 2018, <https://icesat-2.gsfc.nasa.gov/science/ specs>

5. National Aeronautics and Space Administration, "ICESat2: Instrument", Accessed 1 June 2018, < https://icesat.gsfc.nasa.gov/icesat2/instrument.php>

6. National Aeronautics and Space Administration, "A Laser Beam's Path Through NASA's ICESat-2", Accessed 1 June 2018, <https://www.nasa.gov/ feature/goddard/lasers-path-through-icesat-2>

7. National Aeronautics and Space Administration, "ICESat2 (Ice, Cloud and land Elevation Satellite-2)", Accessed 1 June 2018, <https://directory.eoportal.org/web leoportal/satellite-missions/i/icesat-2>

8. Markus, T. et al. "The Ice, Cloud, and land Elevation Satellite-2 (ICESat-2): Science requirements, concept, and implementation", Remote Sensing of Environment, Volume 190, pg 260-273 (March 2017)

9. Canham, J. S., "Investigation of Contamination Efforts on Laser Induced Optical Damage in Space Flight Lasers", Earth Science and Technology Conference for NASA Earth Science Technology Office (June 2004)
10. Abraham, N. S., Hasegawa, M. M., and Straka, S. A., "Development and testing of molecular adsorbe coatings", Proc. SPIE 8492, Optical System Contamination: Effects, Measurements, and Control 2012, 849203 (October 2012)

11. Abraham, N. S., Hasegawa, M. M., and Straka, S. A. "Black molecular adsorber coatings for spaceflight applications", Proc. SPIE 9196, Systems Contamination: (September 2014)

12. Abraham, N. S., Hasegawa, M. M., and Secunda, M. S "Application of the Molecular Adsorber Coating technology on the lonospheric Connection Explore program, Proc. SPIE 9952 , Systems Contamination: (September 2016)

13. Abraham, N. S., "NASA Applications of Molecular Adsorber Coatings", Contamination, Coatings, Materials Science, and Planetary Protection Workshop (July 2015)

14. Abraham, N. S., "NASA Applications of Molecular Adsorber Coatings", Thermal and Fluids Analysis Workshop (August 2015)

15. Abraham, N. S., Hasegawa, M. M., Wooldridge, E. M., and Henderson-Nelson, K. A., "The use of the Molecular Adsorber Coating technology to mitigate vacuum chamber contamination during Pathfinder testing for the James Webb Space Telescope", Proc. SPIE 9952 Systems Contamination: Prediction, Control, and Performance 2016, 99520C (September 2016)

16. Abraham, N. S., "Application of Molecular Adsorber Coatings in Chamber A for the James Webb Space Coatings " Cham A A to Telescope", Contamination, Coatings, Materials Science,
and Planetary Protection Workshop (July 2017)
17. Abraham, N.S., "Thermal Coatings Report TCR \# 730", NASA GSFC Code 546 (April 2016)

18. Jallice, D., "Materials Engineering Report MEB \# 17572", NASA GSFC Code 541 (August 2017)

19. Jallice, D., "Materials Engineering Report MEB \# 18711", NASA GSFC Code 541 (March 2018)

20. National Institutes of Health, "Isopropyl Palmitate", Pub Chem Open Chemistry Database, Accessed 1 June 2018, <https://pubchem.ncbi.nlm.nih.gov/compound/ isopropyl_palmitate\#section=Top>

21. Colony, J.A., "Analysis of Nonvolatile Residue (NVR) from Spacecraft Systems", NASA Technical Memorandum 86184 (January 1985)

22. Kruger, R., "Evaluating a contamination hazard with a residual gas analyzer", NASA Technical Memorandum 19790016899 (January 1978)

23. Mucciacciaro, T., "ATLAS Chemical Analysis Report", NASA GSFC Code 540 (July 2017)

24. Mucciacciaro, T., "ATLAS Chemical Analysis Report", NASA GSFC Code 540 (February 2018)

25. Knipple, J. "Materials Engineering Report MEB \# JK295", NASA GSFC Code 541 (August 2017)

26. Jallice, D., "Materials Engineering Report MEB \# 18009", NASA GSFC Code 541 (February 2018)

27. Jallice, D., "Materials Engineering Report MEB \# 18011", NASA GSFC Code 541 (February 2018) 


\section{Contact Information}

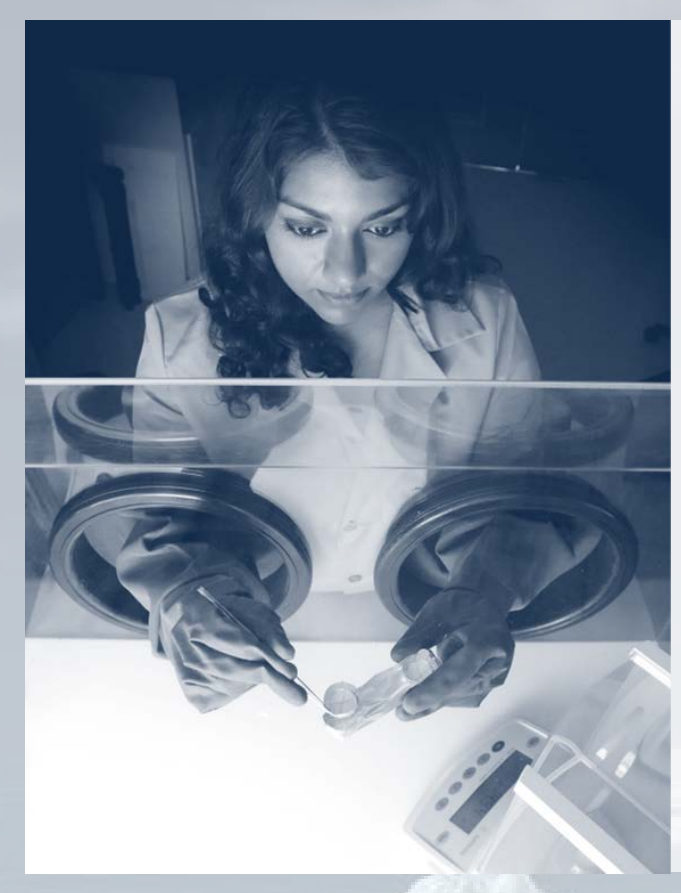

Nithin S. Abraham

Coatings Engineer

NASA Goddard Space Flight Center

Contamination and Coatings Engineering Branch

Code 546 | Greenbelt, Maryland 20771 USA

E-mail nithin.s.abraham@nasa.gov

Phone (301) 614-7070 